\title{
Prevalence and Causes of Child Labor in Gamo Gofa Zone: The Case of Daramalo District
}

\author{
Ezo Emako Kamma \\ School of Graduate Studies, Arba Minch University, PO box 21, Arba Minch, Ethiopia
}

\begin{abstract}
The child labor is worldwide problem. There are estimated over 168 million child labors in the world. About 7.5 million child laborers were found in Ethiopia. This study assessed the reasons for the exploitation of child labor, and the nature and magnitude of problems encountered by child laborers in Gamo Gofa Zone specifically in Daramalo district in 2014/15. The Cox Proportional Hazard model was used and collected cross-sectional data through using systematic sampling method was analyzed by SPSS 20.0. According to the study, the prevalence of child labor was 82.7 percent. Large proportions (99.4\%) of the child laborers in study area are forcefully unpaid family workers and they work starting before 6 am in the morning until $1 \mathrm{pm}$ in the night.
\end{abstract}

Keywords: Child Labor, Prevalence, Cox Regression, Daramalo district

DOI: $10.7176 / \mathrm{JAAS} / 56-04$

Publication date:June $30^{\text {th }} 2019$

\section{Introduction}

The first chapter gives a brief overview of background of the study and central research problem. It also presents objectives of the study, hypothesis, and significance of the study, delimitation of the study and limitation of the study.

\subsection{Background of the Study}

The population of children in world accounts more than quarter of the world population. According to United Nations Department of Economics and Social Affairs analysis, children younger than age 14 made up 26.2 percent of the world population in 2013 (UNESAD, 2013). In absolute term it is more than 1.8 billion children out of seven billion of world people.

According to UNESCO Institute for Statics (2012) data; from 99.8 million in 2000, nearly 58 million children of primary school age (typically between 6 and 11 years of age) were not enrolled in school in 2012 in world. Many of them will probably never enter a classroom (UIS \&GMR, 2014). Also 63 million young adolescents (12 - 15 years old) around the world were not enrolled in primary or secondary school, compared with 97 million in 2000 (UIS \&GMR). More than two thirds of all children out of school live in Sub-Saharan Africa and South Asia. At the same time, millions of children work instead of attending school. The latest global report on child labour, out of total number of children (5-17 years old) greater than 168 million children were considered as Child labor in the world in 2012 but 120 million child laborer found within 5 - 14 age groups (IPEC, 2013). Of course, global number of children in child labour has declined by one third since 2000, from 246 million to 168 million children. More than half of them, 85 million, are in hazardous work (down from 171 million in 2000).

Asia and the Pacific has the largest numbers (almost 78 million or 9.3 percent of child population), but SubSaharan Africa continues to be the region with the highest incidence of child labour (59 million, over 21 percent). There are 13 million (8.8 percent) of children in child labour in Latin America and the Caribbean and in the Middle East and North Africa there are 9.2 million (8.4 percent). Agriculture shares by far the most important sector where child labourers can be found ( 98 million, or 59 percent), but the problems are not negligible in services (54 million) and industry (12 million) - mostly in the informal economy. Child labour among girls fell by 40 percent since 2000 , compared to 25 percent for boys.

The child labor is likely to interfere with the education and normal development of the children which can be harmful to their health and morals. Child laborer's risk to be exposed for abuse, violence and hazards which can be dangerous to their life. Effects of labor on children are not the same as on adults as there are major psychological, physical and social differences between the two groups. Children may be seriously harmed by work which makes little or no risk to adults. Hazardous work during development and growth during the childhood can have lasting effects which can affect the children for the rest of their lives. As a UNICEF 1998 report, Poverty appears to be the major explanation for child labor in the world (Lomi, 2002).

Like in many other sub-Saharan African countries, a large number of children in Ethiopia join the labor force usually below the age of 15. The CSA ( 2001) survey indicated that, around 15.5 million Ethiopian children (85.5 percent of all children) were working. In addition to CSA 2001 survey, Demographic and Health Survey 2011 confirmed that 17 percent of Children between five and eleven year's age and 55 percent of children 12 - 14 years old were engaged in child labor (Zegers, 2013). Solomon and Alemu ( 2003) indicated that 88.8 percent of children engaged in work. According to ILO and ELSAM (2009) study, out of total children 84 percent children were 
labor exploited (UNICEF \& MoFED , 2013). Of all children engaged in economic activities outside the house or household work, about 88 percent reside in rural areas. The highest rates of child labor are to be found in SNNP and Oromia ( 88.8 percent in each). The agriculture sector accounts the largest portion, which is 75 percent and service sector 12 percent and four percent in manufacturing (Guarcello \& Rosati, 2007). This ranks the country among one of the countries with highest rates of child labor in the world. Poverty, lack of educational opportunity parent's choice, children's choice and societal attitudes are main factors in the Ethiopia (Habtamu, 2011).

Late entry of school is a sign of child labor, only about 11 percent of primary school students in Ethiopia are in the appropriate grade for their age; the on-time proportion declines in the higher grades (Primary School Net and Gross Attendance Rates, 2005). Both late entry into primary school and grade repetition can cause children to be over-age for their grade. In 2003, the number of out of school children aged $7-12$ years was 6,147,070; females accounted 54.25 percent (UNESCO, 2003). It shows declined trend but more than 2,813186 children (7 -14 age group) in 2011, still significant number of children are failed to participate in primary school (MOE, 2011).

Child labor is extensively practiced throughout Southern Nations Nationalities and peoples Region (SNNPR); in this regard Wolayita, Gamo Gofa and Gurage are known for child labor and trafficking in the region (Eshetu \&Teshome, 2014). In 2011, more than 493,889.257 students were dropped from school (MOE, 2011). This is one of the highest records.

Likewise Gamo Gofa, Daramalo district is one of high incidence of Child labor with low school enrollment jointly raised. Despite the some measurement actions in the district, still many children participating in the child labor. According to 2012 annual report of Daramalo district administration council, within in the district especially in the agricultural sectors, and outside of the Daramalo, in Arbaminch town many children were participating on economic activities (DMDAC, 2012 ).

\subsection{Statement of the Problem}

Child labor is a complex issue and various factors behind the laboring predominate in different contexts. According to Yacouba, Alex and Farhad (2013), one in ten children in the world are engaged in child labor. Even worse, in SSA, the figure jumps to one in five, representing 47.7 million children out of 220 million.

In Ethiopia there is not comprehensive and adequate study, which shows the exact magnitude and situation of child labor in economic sectors but some studies have accessed the cause and extent of child labor; and attitude of the community towards child laborers. Most of the available studies were limited to the capital city or in most cases; they focused only on certain condition of child labor. The information problem on child labor is further limited by the fact that the bulk of child labor registered in Ethiopia is not wage labor, but labor performed in household where the child live (Solomon \& Alemu, 2006). National Child Labor Survey (2001), the only comprehensive survey on child labor, show that nearly 52.1 percent of the total population in the country engaged in the active workforce. One-half of all five up to fourteen year-olds, more than seven and half million children in absolute terms, were at work in economic activity in the 2001 reference year. The agriculture sector accounts for by far the largest portion of children in economic activity in Ethiopia. Four of five economically active children are in this sector compared with only 12 percent in services and four in manufacturing (Guarcello \& Rasati, 2007). The fertility rate that is estimated at 6.7 percent, according to the $2007 / 8$ report of the CSA, coupled with the subsistence agriculture with backward farming techniques force the population to use the labor of children in both rural and urban settings to survive in Ethiopia (PIN, 2009)

Gamo Gofa zone (GGZ) is one which child labor incidence was high in Ethiopia, found in SNNPR. The children involved in weaving activities in Addis Ababa whose place of origin is in Gamo Gofa Zone of the SNNPR, are forced to work starting from $5 \mathrm{am}$ in the morning until $1 \mathrm{am}$ in the night (Peoples In Need, 2009). United Nations Education Science and Culture Organization (2013) stated that "Although the extent of the problem is unknown, reports indicate that children work in the traditional weaving industry, including in Addis Ababa and in the Gamo Gofa and Wolayita Zones. Child weavers may work long hours, face physical, sexual, or emotional abuse from their employers; and develop injuries as a result of crouching while working on traditional weaving looms". This indicates Gamo Gofa zone is main source of child trafficking and child labor exploitation. This clearly affects the human capital development of the child as manifested by major education indicators. According to CSA (2007) Population and House Census Data, school attendance status indicates that many children were out of formal school, only 11.1 percent $(5,909$ children out of 53,184) of seven years old children were enrolled in school at Zonal level.

Daramalo district is the famous one in the Gamo Gofa Zone, by high incidence of Child labor and Child migration within the district and outside the district. According to Gamo Gofa Zone Women, Children and Youth Department (2012) annual report, above 50 percent of migrated children those live in ArbaMinch especially in Secha sub - city were children migrated from Daramalo district. And they actively participated in hotels, construction works, home works and so on. In the same way, many children participating on the farm activities, micro - trade activities, etc in the district. In Daramalo out of total population76 percent never attended school (CSA, 2007). The elementary school $\left(1^{\text {st }}-8^{\text {th }}\right)$ dropout rate was 24 percent in average. Repetition rate is also 
greater than 10 percent. Total enrollment of school in grade one is not more than 80 percent. These indicate that children go out from school and join the child labor (CSA, 2007).

No meaningful solutions can be proposed without adequately understanding the situations of child workers and the rationale behind the cause of the problem. The existing studies such as ; the study conducted by Abiy (2002), Lomi Yadeta (2002), Solomon and Alemu (2003), Altaye, Ababi, Derege, Mesfin, Menelik, Teferea, Debela and Girmay (2006), Alegnta (2007), Daniel Fekadu (2008), Habtamu (2011), Mebratu, Eshetu and Ejigu (2014), and others concerned in Addis Ababa City and capital city of regions. But most of the children live in rural area as well as child labor were high in agriculture sector. Also these studies emphasized that the child labor incidence is mainly explained by poverty. Up to date possible to say almost all studies used Logit and Tobit models. They are not perfectly convenient to assess the prevalence issues, because they analyze the presence or absence of a certain characteristics but the researcher want to analyze the survival data regarding to child labor. To fill this gap the researcher used Cox Proportional Hazard model. This study used to assess the prevalence and problems of child labor in Gamo Gofa (focus on rural and agriculture). More specifically, the objectives of the study were to describe the socio-economic, personal and demographic situations of child laborers; describe the magnitude and severity of the problems; identify and analyze factors that contribute to child labor; statistically test the determinates and recommend possible strategies for interventions that can alleviate the problems of child laborers.

\subsection{Objectives of the study}

\subsubsection{General Objective}

The general objective of this study is to assess the prevalence and causes of child labor and analyzing its effect on child schooling.

\subsubsection{Specific objectives}

$>$ To analyses the incidences, profile and socio - economic causes of child labor.

$>$ To evaluate working conditions and working schedule of child labor.

$>$ Identifying levels and circumstances under which activities become a potential threat to a child's development.

$>$ To examine the existence of gender bias, through child - work rotation.

$>$ To assess school enrollment, dropout and repetition of children.

$>$ Suggest policy options in order to reduce child labor in Gamo highlands as well as at country level.

\subsection{Hypothesis of the study}

$>$ Poverty positively related with child labor.

$>$ There is a negative correlation between school attendance and child labor.

$>$ Sex difference especially female has positive relation with child labor.

\subsection{Significance of the study}

This study used to indicate directions for designing programs to reduce child labor in the area and areas that need the government interventions, NGO's and other bodies concerned for the safety of children in the study area and other parts of the country that have similar socio economic and cultural background. The study gives practical insight to the situation of child workers in the informal sector in the area especially in Agricultural sector. The result of the study provides policy related information that helps to prioritize among the many possibilities depending on the relative extent of influences of its determinants. Finally, very little is known about causal factors (demand and supply) that cause child labor that is specific to the study area. The research also gives information on the causal factors, which are particularly relevant to the study area. Lastly, this study attempts to make further contribution to the previous studies and can be used as a source material for further studies.

\subsection{Delimitation and deficiency of the study}

The study limited to Daramalo district and children those aged 5 -14. Also it analyzed the prevalence and causes of child labor and its effect on child education. Since the unit of analysis was children and there was no birth registration in study area, it made difficult to record exact age of children in some cases. So, this was taken as a deficiency in this research work.

\subsection{Organization of the Paper}

The rest of this paper organized as follows; Chapter two concerned with review of literature and the third chapter presents a brief description of methodology part. The fourth and the fifth chapters represent the result and discussion part and the conclusion and recommendation part respectively.

\section{Literature Review}

This chapter mainly presents a critical and in depth evaluation of researches conducted on the area of child labor 
in previous years. It is summary and synopsis of a child labor area of research, allowing anybody reading the paper to establish why the researcher pursuing this particular research program. Therefore, it reviews the concepts and definitions, theoretical and empirical reviews as well as theoretical and conceptual frame works of child labor in the next section.

\subsection{Concept and Definition of Child and Child Labor}

Despite there exist a wide array of and growing empirical literature on child labor, theoretical writings on the area are scanty. Regarding to the definition of the child labor, there is no simple definition of child labor, as well as child work neither is there universally accepted criteria as to what constitutes child labor or child work. On the literature there has been a semantic argument on the issue for long. The argument starts from the language usage itself since many languages do not have words that consider child labor and child work separately. On the other hand some argued that the labor work differentiation doesn't involve the children themselves.

Different countries have different minimum age in their national legislation. ILO Convention No. 138, adopted in 1973, sets 15 as the minimum age for work in developed countries, in normal circumstances, but a child can become an apprentice at a younger age (14 years) or undergo vocational training. Following this, most studies treat a person of age less than 15 years as a child. Thus for light work the age limit is 13 years and for hazardous work it is 18 years (ILO - IPEC, 2013).

Table 1. ILO Minimum Age Convention No. 138

\begin{tabular}{lll}
\hline & General minimum age & Exception (developing countries) \\
\hline Basic minimum age & 15 years & 14 years \\
Hazardous work & 18 years & No exception \\
Light work (Art. 7) & $13-15$ years & $12-14$ years \\
\hline
\end{tabular}

Ethiopia has ratified the ILO Minimum Age for Admission to Employment Convention of 1973 and the ILO Convention against the Worst Forms of Child labor. Besides International Conventions, the country has instituted protection for children in its constitution which provides that children under 18 have a right to be protected from work that is exploitative, hazardous or otherwise inappropriate for their age, detrimental to their schooling, or detrimental to their social, physical, mental, spiritual or moral development.

The term child labor is often defined as work that deprives children of their childhood, their potential and their dignity, and that is harmful to physical and mental development. It interferes with their schooling: by depriving them of the opportunity to attend school; by obliging them to leave school prematurely; or by requiring them to attempt to combine school attendance with excessively long and heavy work (ILO,2004).

Hazard type and worst form of works have serious effect on child. The Worst Forms of Child Labor Convention No. 182, states that it includes slavery, forced labor, sale and trafficking of children; forced recruitment of children for use in armed conflict; use of children in prostitution, illicit activities; and hazardous work. According to IPEC (2012);

In general, hazardous work conditions include night work and long hours of work, exposure to physical, psychological or sexual abuse; work underground, under water, at dangerous heights or in confined spaces; work with dangerous machinery, equipment and tools, or which involves the manual handling or transport of heavy loads; and work in an unhealthy environment which may, for example, expose children to hazardous substances, agents or processes, or to temperatures, noise levels, or vibrations damaging their health.

Not all work done by children should be classified as child labor that is to be targeted for elimination. The ILO often distinguishes between child work and child labor, the latter being used to describe the more pejorative part of child work, whereas child work in itself could including doing light household chores and can actually have some learning value. Children's or adolescents' participation in work that does not affect their health and personal development or interfere with their schooling is generally regarded as being something positive. This includes activities such as helping their parents around the home, assisting in a family business or earning pocket money outside school hours and during school holidays. These kinds of activities contribute to children's development and to the welfare of their families; they provide them with skills and experience, and help to prepare them to be productive members of society during their adult life.

\subsubsection{Legal Frame Work of the Child Labor}

In world different laws, directives, decree and convections adopted regarding to children. The UN Convention on the Rights of the Child was adopted unanimously without modifications by the General Assembly of the United Nations on 20 November 1989. In 1999, the Worst Forms of Child Labor Convention No. 182 was adopted at the International Labor Conference in Geneva states the worst form of child labor, it includes slavery, forced labor, sale and trafficking of children; forced recruitment of children for use in armed conflict; use of children in prostitution, pornography, illicit activities; and hazardous work.

The Twenty-sixth Session of the Assembly of Heads of State and Government of the OAU, in Addis Ababa, Ethiopia, July 1990, adopted the African Charter on the Rights and Welfare of the Child. The Charter came into 
force on July 2001, after its ratification by the required 15 states. Ethiopia has not yet ratified it (SA, 2003).

In the same way Ethiopia ratified international conventions and formulated national laws. Some of them are described as follows. The Ethiopian Civil Code of 1960 defines the Child as a minors and minor defined as person of either sex who has not attained the full age of 18 years. Since childhood is defined in terms of age, age is one of the most important variables that define the nature of the work performed by children.

According to Article 37 of the Ethiopian Civil Code, the birth of a child has to be declared and registered with the commune where the child was born within 90 days following his/her birth. However, insufficient steps have been taken to ensure the registration of children after birth. The State registration procedure is hampered in practice by the lack of registration desks, especially in rural areas. It is also evident that there is a lack of adequate means for the registration of refugee children.

Regardless of the clear legal provisions of the 1960 Civil Code of Ethiopia and the 2000 Revised

Family of Code of Ethiopia, which has articulated the need to establish a national Birth Registration system, an office necessary to carry out the task of registration is not yet set up and an appropriate vital statistics registration system has not yet been installed. As a result of the neglect of birth registration system in Ethiopia, protection of child rights like the right to have a name and nationality, the right to know parents and get their care, the right of the child to be protected against abuse and exploitation, the right of the child not to involve in armed conflict, the rights of children conflicting with the law, the right of access to social service, and he right to participate in the political life of the country are being affected (Zewdineh, 2008).

In the Ethiopian Civil Code it says, "Once the parents of the child are ascertained, these parents have the obligation to care for their child because "the child has the right to be cared for by his parents" (Article 7 (1) UN CRC). In addition the Ethiopian Civil Code states that the primary responsibility of caring of children rests on parents. The father and mother of the child are responsible for their upbringing (Article 637 of the Civil Code).

The obligation of parents to care for their children is also addressed in Article 808 of the Civil Code in the form of the obligation to supply maintenance, i.e. to feed, lodge, clothe and care for a child's health in a decent manner. Failure to perform these obligations is punishable under the Penal Code, Article 625.

The State is under the obligation of taking measures that prevent sales of or traffic in children and abduction of children (Article 35 UN CRC). The Ethiopian Penal Code punishes any person, including a parent and guardian who engage for gain in the trafficking of children under the age of 15 years, whether by seducing, enticing, procuring them or inducing them to engage in prostitution. This punishment is aggravated where the victims are under 15 years of age, or are entrusted to the care of the offender who has taken advantage of his/her position, or used trickery, fraud, violence and intimidation (Penal Code, Article 606). Anyone who facilitates or organizes traffic in infants or young persons, are also punishable with imprisonment (Penal Code, Article 607).

Under the 1957 Ethiopian Penal Code it is stated that the minimum age of criminal responsibility is 9 years and that as from the age of 15 years, children are treated as adults (Article 56:1). In this regard it is not clear, whether the latter means that children above 15 years of age may be sentenced to life imprisonment or detained together with adults.

Under the Ethiopian Civil and Penal laws the child's right to life is protected in three ways. One is by threatening penal sanctions against those who commit, attempt or incite murder or other acts likely to lead to death, including aiding suicide and committing genocide. This sanction may even go to the extent of protecting the life of the unborn child. The other means of protecting the right to life is more lenient than the one already discussed. It is taken by way of giving the survivors of the deceased person the right to sue for damages. The third protection is unique to children. Under the Ethiopian Penal Law it is strictly prohibited to impose death sentences on persons below the age of eighteen, however grave the offence may be. This by itself constitutes one of the mechanisms of ensuring that the child is exercising his right to life.

Ethiopia has ratified UN Convention on the Rights of the Child, ILO Minimum Age Convention No. 138, and ILO Convention No. 182 on the Worst Forms of Child Labor. UN Convention on the Rights of the Child has been ratified by Ethiopia. It protects the child from economic exploitation, sexual exploitation, sales and traffic, recruitment in armed conflicts, participation in illicit production and trafficking of drugs etc. Ethiopia has ratified the Convention on the Rights of the Child by Proclamation No.10/1992. ILO Minimum Age Convention (No.138) was ratified by Ethiopia in 1999. It places on the ratifying States the obligation to fix a minimum age admission to employment. ILO Worst Forms of Child Labor Convention (No182) has also been ratified by Ethiopia. The Convention defines the worst forms of child labor. OUA charter was not ratified by Ethiopia.

The State of Ethiopia adopted a new and currently existing Constitution in December 1995, which improved in many ways the legal protection of children. Article 36 of the Constitution pertains specifically to the rights of children, and was drafted taking the provision of the $\mathrm{CRC}$ in to account.

Article 36 of the Ethiopian Constitution:

Every child has the following rights:

$>$ The right to life

$>$ The right to obtain name and nationality 
The right to know and be cared for by his parents or legal guardians.

$>$ The right to be protected from labor exploitation and not to be forced to undertake work that may harm his/her education, health and well-being.

$>$ The right to be free from harsh or inhuman punishments that may be inflicted on his body, in schools or child care institutions.

Sub article one (d) states every child has right not to be subject to exploitative practices, neither to be required nor permitted to perform work which may be hazardous or harmful to his or her education, health or well-being.

The Labor Proclamation of Ethiopia Proclamation No. 377/2003 stipulates that the minimum age for employment is 14 years. Children below the age of 14 are not allowed to work at all. According to the proclamation the 14 years age is put as a bottom line for the labor market in the country. Employment in hazardous work is also forbidden for those under 18. Nevertheless children in the age group of 14-17, are only employed or enter into employment contracts with a list of conditions that are presented in the labor law. According to the proclamation in Chapter 2 Article 89 Sub-Article 3 "It is prohibited to employ young workers which on account of its nature or due to the condition in which it is carried out, endangers the life or health of the young workers performing it. SubArticle 4 of the same Article lists the list of activities that the Ministry might prohibit child employees in the age group of 14-18 as follows;

a) work in the transport of passengers and goods by road, railway, air and internal waterway, docksides and warehouses involving heavy weight lifting, pulling or pushing or any other related type of labor;

b) work connected with electric power generation plants transformers or transmission, lines;

c) underground work, such as mines, quarries and similar works;

d) Work in sewers and digging tunnels.

The Labor Proclamation also prohibits all children from working at night, and working overtime.

Ethiopian Labor Law 377/2003 states that there are two categories of minors: Persons under 14 years of age and "young workers", persons who have attained the age of 14 years but are not over 18 years of age (LLE, 2004). The first category of minors is totally prohibited from contracts of employment. In the case of the second category of minors, they can sign employment contracts for work and apprenticeship. Legally speaking, persons below the age of 18 are minors and due to this status they are not allowed to enter into juridical acts personally. As we all know, entering into a contract of employment is a juridical act. Hence it must be noted that the issue of young employees is an exception to the general rule. This Labor Law goes against Article 313 in the Civil Code, which forbids young workers to undertake professional contractual relationships with an employer. Finally, the Labor Law treats a person as an adult worker only when he is over eighteen years of age; otherwise he is a minor or a child.

Recent changes in the Family code (July 2000) provides children with a right to be heard in divorce cases, marriage and child custody.

\subsubsection{Cut Off Time of Children Work}

Many researchers discuss mainly the effects of child labor by considering whether the child is working or not, without devoting much attention to the number of hours actually worked. While these studies offer some evidence on the matter, it is important to assess not only the causes of child labor, but also the duration of work.

According to International Labour Organization (ILO), UNICEF and World Bank (2001) joint study in Pakistan and Nicaragua claim often made that children working less than two or three hours a day should not be considered as "working” children ((F. Rosati, M. Rossi, 2001). Also Ranjan Ray and Geoffery Lancaster (2003) states that "Work that does not negatively impact on the child's schooling, is found to be 10.54 hours per week for service, shop and market sales workers and 10.88 hours a week for agricultural workers".

\subsection{Theoretical and Empirical Review}

The researcher begins with a discussion of the existing theories that concerned child labor. Empirical implementation (empirical findings) of theories will be discussed in preceding section after theoretical presentation.

\subsubsection{Theoretical Review of Child Labor}

The human capital theory is one of the most popular and important theories that can be used on the discussion of educational investment and economic growth. This theory argues that obtaining education eventually increases productivity, labor quality and income at both individual and national levels (Schultz, 1964; Gillis, Perkins, Roemer, \& Snodgrass, 1996 as cited Masuhama, 2000). At the macro level, Becker (1997) as cited in Masuhuma, economies tend to grow faster when the countries have wider educational bases and the majority of their populations are literate. At the micro level, Jensen and Nielsen (1997) as cited in Masuma describe how years of schooling can be used as one of the proxies for earning potentials at the individual level, according to this theory. Child labor interferes with human capital accumulation and may affect the present and future health of the child. It is a well-known fact that many children, especially those who live in less-developed countries, work full/part time, either paid or unpaid. Some of them combine school and work, and others are solely engaged in work without 
attending school. Hours spent at work reduce time available for study, tire the child and reduce their learning productivity.

There are many other theoretical models regarding to child labor were formulated by different individuals. But the researcher reviewed some of them which are more related to his research topic. They described as follows:

A Basic Model of Household Decision-Making is most widely used model regarding to child labor to describe the supply side of child labor. As pointed out by Strauss and Thomas (1995), they had immediate intellectual roots in Japanese agricultural economics in the 1950s and Becker's work of the 1960s. These models are quite general and may apply to child labor anywhere. To put it simply, in these models a family utility function is maximized under an income and/or production function constraints and a time budget constraint (Bardhan \& Udry, 1999).

The theories mentioned above can be simply summarized as follow: each household maximizes its utility, a function of household consumption $\mathrm{C}$, child schooling $\mathrm{S}$, and child leisure 1, subject to budget and time constraints:

$\operatorname{Max} U(C, S, l)$ (1)

$\mathrm{C}, \mathrm{S}, 1$

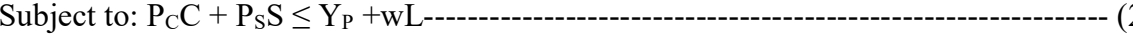

$\mathrm{S}+\mathrm{L}+1=\mathrm{T}$----------------------------------------------------------------------------(3)

where $\mathrm{P}_{\mathrm{C}}, \mathrm{P}_{\mathrm{S}}, \mathrm{w}$ are consumption goods price, schooling cost, and child wage, $\mathrm{Yp}$ is parental income, and $\mathrm{L}$ and $\mathrm{T}$ are child's labor and total time.

Solving the model gives four hypotheses: firstly, when returns to adult labor are low (i.e., low parental income) there will be less child leisure, less school, and more child work. Secondly, when schooling is expensive there will be less school, more leisure, and more work. Thirdly, in the case that child labor has high returns (more opportunities to work, good wages) schooling and leisure decrease, and work increases - both income and price effects are present but the result with probably be dominated by the price effect. Fourthly, there will be more schooling, less leisure, and less work if expected returns (or utility) to schooling are high. Finally, there is the issue of preference, i.e., children will work if parents have a high preference for work.

Basu and Van (1998) are the authors of the seminal paper on the topic of subsistence poverty and child labor. Their model builds on two fundamental assumptions, which they refer to as the Luxury Axiom and the Substitution Axiom. The Luxury Axiom states that a household will send its children into the labor market only if the adult wage falls to the point where the household subsistence requirements cannot be met without the income generated by the children.

Household preferences defined over pairs $(\mathrm{C}, \mathrm{e})$ for $\mathrm{c} \geq 0$ and $\mathrm{e} \in(0,1)$.

Preferences are

$$
\begin{aligned}
& (\mathrm{C}+\delta, \mathrm{e})>(\mathrm{C}, \mathrm{e})---\cdot--- \\
& (\mathrm{C}+\delta, 1)>(\mathrm{C}, 0) \text { if } \mathrm{C}<\mathrm{S} \\
& (\mathrm{C}+\delta, 1)<(\mathrm{C}, 0) \text { if } \mathrm{C} \geq \mathrm{S}
\end{aligned}
$$

For $\delta>0, \mathrm{C} \geq 0$, e $(0,1)$

Where: $\mathrm{C}$ - household consumption, e - child labor effort, $\mathrm{S}$ - subsistence level consumption of household. The household budget constraint is

$$
\mathrm{C}+\mathrm{m} \beta \mathrm{c}=\mathrm{meWc}+\mathrm{Wa}
$$

Where: $\mathrm{C}$ is adult consumption, $\mathrm{m}$ - number of children, $\mathrm{Bc}-$ consumption per child, $\mathrm{Wc}-$ wage of child and $\mathrm{Wa}$ - wage of adult.

$$
\mathrm{e}=\mid \begin{aligned}
& 0 \text { if wa } \geq(1+\mathrm{m} \beta) \mathrm{s} \\
& 1 \text { if wa }<(1+\mathrm{m} \beta) \mathrm{s}
\end{aligned}
$$

If, however, parents are not altruistic towards the children, child labor occurs as the result of the welfare maximizing process in which it is treated entirely as consumption good, is called the substitution axiom. The Substitution Axiom states that adult labor and child labor are seen as substitutes from the point of view of the firm. More specifically, child labor can be substituted by adult labor. A further assumption, which is not stated explicitly, is that the labor market functions perfectly (as the results rely upon labor market equilibria and competitive wage setting).

Ranjan (1999) develops a two period model where households decide whether to send their children to work or to school in the first period. There are two types of adult wages, the skilled wage and the unskilled wage, and one child wage, which is less than the unskilled adult wage. Further, there is no subsistence constraint. A child that works in the first period earns the child wage in the first period and the unskilled adult wage in the second period. A child that goes to school in the first period earns nothing in the first period, but earns the adult skilled wage in the second period. In the first best case, households have access to the international capital market and can lend and borrow freely at a given interest rate, $r$. Ranjan's model demonstrates that in this case households will always prefer to send their children to school as long as the rate of return on education, i, exceeds the market rate of interest (i.e. $i>$ r), regardless of the initial level of house- hold income. In the case with no credit markets, Ranjan demonstrates that there is a threshold level of household income above which all families will send their children to school, whereas below this level all households will be forced to send their children to work. These 
results reveal that poverty will not prevent households from sending their children to school if they are able to borrow and if educational attainment is profitable.

Baland and Robinson (2000) analyze whether or not child labor is inefficient when households face a credit constraint. They develop a two period model where parents supply labor in- elastically in both periods and decide how their child allocates its time between work and school attendance. The more time a child allocates to schooling, the higher its second period income will be. Parents also decide the level of savings in the first period and the level of bequests to the child in the second period. In the first case, children cannot make credible promises to compensate their parents in the second period for forgone income in the first period and parents cannot borrow. They show that under these conditions, child labor will only be efficient if both savings and bequests are positive. If either, or both, of these are zero, however, the equilibrium level of child labor will be inefficiently high. When bequests are zero but savings are positive, child labor serves as a means of transferring income from the child to its parents. When savings are zero and bequests are positive, child labor is a means of transferring income from the future to the present. This is because even though the parents fully internalize the negative effects of child labor on the child's second period income, they value first period consumption higher than second period consumption.

Ray (2002) constructs a collective household model in which the balance of power between husband and wife affects how much children work. In this model, the more balanced the bargaining power of husband and wife is, the less the children in the household have to work.

This assumes that both parents are altruistic and so do not like sending their children to work, and that the two parents have different preferences over the goods consumed by the household. The outcome of their model is a U-shaped relationship between the balance of bargaining power between husband and wife and child work.

Bhalotra and Heady (2003) refer to this as the wealth paradox, in order to explain the wealth paradox; they turn to labor and land market imperfections. The wealth effect is the result of a productive asset's ability to generate income and tends to have a negative effect on child labor: households with larger holdings of productive assets will tend to have higher incomes, making it easier for these households to forgo the income generated by child labor. Further, if capital markets are imperfect then households with large holdings of land will be more likely to gain access to credit at lower interest rates, as land can serve as collateral. This in turn reinforces the wealth effect of land.

Bacolod and Ranjan (2008), who look at the interaction between wealth and child ability as determinants of child labor and schooling, they construct a theoretical model and provide empirical evidence, using data from the Philippines', suggesting that while poor households with high ability children are more likely to send them to school than poor households with low ability children, the latter are more likely to let the children remain idle rather than work.

\subsubsection{Empirical Review of the Child Labor}

Regarding to human capital accumulation, many previous studies empirically showed the harmfulness of child labour to human capital accumulation. For example, using time-log data of children from a Tanzanian household survey, Akabayashi and Psacharopoulos (1999) as cited Ranjan Ray and Geoffrey Lancster (2003) observe (p.120) "that a tradeoff between hours of work and study exists....hours of work are negatively correlated to reading and mathematical skills through the reduction of human capital investment activities". Heady (2000) similarly observes on Ghanaian data that "work has a substantial effect on learning achievement in the key areas of reading and mathematics....these results confirm the accepted wisdom of the negative effects of work on education".

Rosati and Rossi (2001), using data from Pakistan and Nicaragua, conclude that an increase in the hours worked by children significantly affects their human capital accumulation. Ray (2000)Ray, using information on educational attainment from the $50^{\text {th }}$ round (July, 1993 - June, 1994) of India's National Sample Survey found that, in both rural and urban areas, the sample of children involved in economic activities recorded a lower mean level of educational experience than non working children.

Many researchers used poverty as a main variable that affect the child labor. Based on the theoretical presentation, reviewing empirical realities enable the readers and concerned bodies for easily understanding. According to ILO child labor commonly may represent around 20 per cent of the household income, and as poor families spend the majority of its income on food, consequently the children's incomes are crucial. Among the studies, Krueger's work (1996), this demonstrates a strong correlation between child labor and poverty. The World Bank (1998) reports that the labor-force participation rate of children aged ten to fourteen years is highest, 30-60 percent, in countries with per capita income of $\$ 500$ or less (at 1987 prices). But it declines quite rapidly, to $10-$ 30 percent, in countries with incomes between $\$ 500$ and $\$ 1,000$.

Grootaert finds a clear positive correlation for Côte d'Ivoire between the degree of poverty and both participation rates and hours worked by children in the seven up to fourteen age group, in 1988. In the rural areas, 79.6 percent of the children of the rural extreme poor worked, on average, 1,742 hours per year, while 19.4 percent of the non - poor worked, on average, 1,558. Constituting 26.3 percent of the total labor supply of the poor households and only 8 percent for the non-poor, child labor appears to be much more important for the survival of poor households, even when we consider the household's own use of the children's labor power. 
The empirical results of Admassie (2002) study confirmed by Tobit analysis clearly and strongly assert a positive and robust relationship between the incidence of poverty and child labor in sub- Saharan Africa. According to descriptive analysis of Solomon and Almu (2006), poverty accounts 60.7 percent among variables those causes child labor in three major towns of southern Ethiopia (Awassa, Wolaita soddo \& Arbaminch).

In contrast to these empirical evidences, some studies indicate that child labor and poverty have either weak correlation or negative. For instance, in Pakistan, Ray (1998) found that improved household welfare did not determine children's participation in the labor market. Chandrasekhar's (1997) study also claims that there is a weak correlation between child labor and the incidence of poverty. Andving (2001) points out that the relation of national income and child labor participation (using ILO statistics) is weak in a sample of African countries. This is consistent with the fact that virtually all child labor in sub-Saharan Africa is family-controlled and that labor markets are relatively underdeveloped in this region.

Other researchers who have not been able to establish a positive link between the incidence of poverty and the incidence of child labor include Nielsen (1998) and Canagarajah and Coulombe (1997) cited in (Andvig,Canagarajah \& Kielland, 2001).

Education and occupation of the parents is another important factor behind child labor. The more education parents, particularly mothers, have - the less likely they are to let their children work. They may not weigh the costs and benefits of forgone labor now to see higher rates of return in the future. If a parent worked as a child, his/her child is even more likely to work. Also, mothers who work outside of the house are more likely to have female children who work, as the children are forced to take over the absent mother's responsibilities, in lieu of attending school. Families in Peru cite school quality as the biggest factor for child work force participation (Brown 2001 cited in Gordon 2008). Primary schools rarely have the resources to provide adequate education, which leads to the assumption that children are better off working than attending school.

Inaccessible education has significant effect on child to be child laborer. Myron Weiner and others argued that: "No country has successfully ended child labor without first making education compulsory. As long as children need not attend school, they will enter the labor force." Policy makers in most countries believe that mandatory education is a prerequisite for the eventual abolition of all forms of child labor (Weiner 1990 cited in ILO, 2004).

When children work full-time, school dropout and repetition rates tend to increase, with the result that older children find themselves in classrooms with younger ones. Children are less motivated to do good schoolwork (sometimes because they are just too tired), and school failure is often the result. According to the study most children especially in rural parts of the country fail to continue their education due to work load, inability to cover the costs related to education such as education materials and cloths. Ray (2007) examined the child labor in India. $\mathrm{He}$ found that an increase in female education within a household decreases child labor. Canagarajah and Coulombe (1997) could only find weak negative correlation between school and labor participation rates for Ghana (Andvig,Canagarajah \& Kielland, 2001).

The gender differences are striking in child labor. Many societies send their boys to school, not the girls and the older siblings are more likely to be sent to work than the younger ones. When age became advanced the incidence of children become high. According to World Bank (1998) household labor needs are the predominant cause of non-enrollment for girls where as farm works are for boys. Reynolds (1991) claims, using one method of time registration, that in her poor Tonga village in Zimbabwe, the girls spent 65 percent of their working hours on labor, while the boys in the same age group only worked 25 percent of their time. This is an extreme result, but a similar study from Giriama on the coast of Kenya (Wenger 1988) observed that, in the eight to 11 age group, girls spent 51 percent of the time working (daylight hours), while the boys only worked 26 percent.

A research titled as Socio-economic correlates of child labor in agricultural sector of rural Rajshahi District in Bangladesh in 2010 was conducted by Rahman, Islam and Tareque multivariate logistic regression analysis result indicates: Largest percentages of the child labor are male (90.2 percent). The Central Statistics Agency of Ethiopia 2001 Survey report shows that the participation rate in productive activities was 62 percent for boys and 42 percent for girls. For domestic activities, this figure was 22 percent for boys and 44 percent for girls. A study conducted in Ethiopia indicates that the economic activity rate of male children exceeds that of female (Gurcello, Lyon \& Rossati, 2006). According to WB report in 2009, single head of household, generally a woman is one variable that seems to be closely linked with high prevalence of child labor (Johansson, 2009).

Boys with single mothers are especially likely to undertake laboring in order to contribute to the family economics (Johansson). Child labor in Nigeria and its economic implications - a case study of Calabar municipalicity conducted by Ndem, Michael and Awa (2012) survey, discovered that the number of the girls engaged in hawking represent 33 percent of the number of child hawkers surveyed as against 21 percent of boys.

\subsection{Theoretical and Conceptual Framework of Child Labor}

Child labor can have significant economic consequences at both household and national levels. In the short run child labour significantly increases the income and the probability of survival of the family. Several estimates exist 
of the proportion in which children contribute to family income: for instance Cartwright and Patrinos (1999) as cited in Galli, 2001 find that children in urban Bolivia contribute on average around 21 percent of family income; Usha and Devi (1997) find a similar figure (on average 20 percent) for child labourers from a village in Tamil Nadu (India); and Swaminathan (1998) reports that 40 percent of children in her sample (Gujarat, India) contributed between 10 percent and 20 percent to total household income (Galli,2001). This contribution is most of the time critical since children are sent to work when parents' earnings are insufficient to guarantee the survival of the family, or are insecure so that child labour is used as a mean of minimizing the impact of possible job loss, failed harvest and other shocks on the family's income stream. In these circumstances, the survival of the family depends on child labour irrespective of whether it is carried out in hazardous or non-hazardous activities, in formal or informal economy, or even in paid or unpaid family activity.

Since human capital production is an ongoing process, it is clear that the returns to human capital investments in later adolescence depend critically on earlier investments and that remediation, while not impossible, is comparatively expensive (Knudsen et al. 2006). Galli (2001) looks at the negative effects of child labor and recognizes six channels through which child labor might affect a country's long run growth: Lower human capital accumulation, higher fertility, worse health; slower investment and technical change, higher income inequality and higher gender inequality.

Effects through human capital: To the extent that child labor impedes children's school attendance, proficiency and human capital accumulation, it depresses a country's labor productivity and growth in the long run. Since child labor competes with school attendance and proficiency; children sent to work do not accumulate (or under-accumulate) human capital, missing the opportunity to enhance their productivity and future earnings capacity. This lowers the wage of their future families, and increases the probability of their offspring being sent to work. In this way poverty and child labor is passed on from generation to generation. The empirical findings demonstrate that early entry to the workforce reduces lifetime earnings by 13 percent to 20 percent. Child labor also raises the probability of being poor later in life by 13 percent to 31 percent (Ilahi, Orazem \& Sedlacek, 2005).

The size of the negative impact on future productivity of child laborers obviously depends on the degree in which work affected their school attendance and progress and their accumulation of working skills. With respect to school attendance and progress, full-time jobs have the worst impact on children future productivity. Part-time jobs, especially those that are physically very demanding, also disrupt education since children are too tired to participate adequately at school activities or to study at home. Child labor and schooling are not necessarily mutually exclusive. Several studies find that in developing countries many children who attend school also work.

However, part-time child labor can still be harmful for human capital accumulation since it competes with other human capital developing activities such as time to study at home. Moreover, low education is associated with lack of awareness of rights and of democratization, negatively affecting growth (democracy is a determinant of international competitiveness) and social development (non-democratic governments obviously limit people's freedom). By the same token, a successful reduction in child labor should lead to higher human capital accumulation, long run growth and development.

Child labor has a negative long run impact on the well being of the family also through increased fertility. In fact child labor lowers the perceived cost of having children thereby boosting fertility. Larger family size in turn fuels the need for the income provided by children, generates child labor supply and impedes the education of the future generation of parents. Since parents' lack of education is one of the most important determinants of high fertility, large families needing the income from child labor perpetuate over time (Anker and Melkas, 1996 cited in Galli 2001).

As cited in Galli 2001, seminar paper by Rosenzweig and Evenson (1977) on "Fertility, Schooling, and the Economic Contribution of Children in Rural India: an Econometric Analysis" provides strong empirical evidence that "one of the basic conditions motivating Indian families to bear relatively large numbers of children in the late 1950 's was the high return to the use of raw labor power of children compared to investments in skills obtained in schools". The existence of child labor in fact enhances the national birth rate both directly (through the lower perceived cost of having children) and indirectly (through lower education), and higher national fertility inflicts a well-known cost in terms of growth.

Child labor can affect negatively a country's long run growth also through health. The health problems caused to child laborers, especially those working in hazardous activities, and the lower hygiene associated with scarce education translate in the long run into a less healthy and hence less productive adult labor force, subtracting from long run growth.

Child labor can depress long run growth also by slowing down technological progress. The availability of cheap, unskilled child labor in fact allows employers to avoid investing in fixed capital and upgrading production processes, thereby dampening technological progress, labor productivity and output growth in the long run. The empirical evidence confirms that production processes involving child labor are generally carried out in the unorganized sector and in small units with simple production technologies and relatively little capital (Anker et al., 1998 cited in Galli 2001). 
According to Anker et al (1998), most employers who rely on child labor are uneducated and poor, and hire children to survive in the low-margin highly competitive informal sector (Galli, 2001). Once child labor - their most important profit source - is removed, the cost of unskilled labor is likely to go up. To the extent that this will happen, poor employers will go out of business. The disappearance of these small enterprises, however, may well induce the bigger enterprises to undertake investment and technological innovations.

Effects through income inequality: Child labor certainly has an impact on income inequality, but the direction of this impact might be ambiguous and could vary in the short and in the long run. In the short run, child labor provides poor families with the income they need for their survival. From this point of view, therefore, child labor lessens income inequality, by raising the income of those at the bottom of the distribution. On the other side, it is often argued that child labor adds to the supply of unskilled labor, in this way depressing the wage rate of unskilled adults. This, of course, makes the distribution of income more unequal.

The net effect on income inequality in the short run therefore depends on the size of the unskilled adults wage loss relative to the children wage rate. A different story works in the long run. As explained above, child labor negatively affects the income of the involved families and of their descendants through mutually reinforcing low education and high fertility. At the same time, the scarce supply of educated labor keeps the skilled workers wage rates at high levels. Therefore in the long run there is no doubt that child labor worsens, or at least perpetuates, income inequality. Income inequality, in turn, directly reduces a country's level of social development. Moreover, income inequality is likely to have a negative effect on long run growth (Benabou 1996 \& Aghion et al. 1999, cited in Galli 2001) and, therefore, to have a further indirect negative effect on social development.

Higher gender inequality in contexts where children's work activities are based on gender, school attendance can be affected along gender lines too. Sometimes in favor of boys' attendance, sometimes in favor of girls, depending on influences of the cultural context, this in turn can lead to higher gender inequality in a society. Knaul (1998) reports that in Mexico among all children and youth aged 8 to 17, seven point six percent of young women as compared 16.8 percent of boys were employed in market-based work (Galli, 2001). On the basis of official statistics thus child labour seems biased against boys. However, a more careful look at the statistics is revealing.

The 1991 Census of India reports that 56.6 percent of five to 14 year old boys were in schools, five point two were in full-time economic activities, zero point five were marginal workers, and 37.7 percent were nowhere (Galii), i.e. participated to household activities not classified as gainful employment. Chaudri (1997) as cited in Galli, the figures for girls of the same age group are 44.2 percent in schools, three point four percent in labour force, one point seven marginal worker and 50.7 percent nowhere. So more than a third of boys and one out of two Indian girls did not attend school in 1991 but at the same time were not considered as child labourers.

Much of the reviewed literature on child labor concentrated on examining the relation between poverty and child labor, and schooling and child labor. Many researchers conducted their research in the urban area by using secondary data. Up to date possible to say almost all studies used logistic regression. Logistic regression is not perfectly convenient to access the prevalence issues. To fill this gap the researcher proposes to use Cox proportional hazard model. Many studies give a contradicting result in some variables. And most researches attention was not given to agricultural sector. In sum, from the above literature review different empirical studies gave different implication. It may be due to methodology difference or quality of data or data quality. For instance in some studies poverty and child labor have strong relation where as in other studies it is weak. In the same way regarding to child labor and school, wealth paradox, labor and land market imperfections there were different feelings. Therefore these critics are one of starting points for this study to show the causes clearly in the study area.

\section{Methodology}

This chapter describes specific procedures that the researcher anticipates adopting for his thesis. In other words, this section succinctly articulates specific procedures for addressing the researcher's research problem and what the researcher intended to do to answer his research questions. The methodology chapter includes location of the study, research design, total and sample population, sampling procedure and sample size, data gathering instruments, model specification and data analysis ways.

\subsection{Description of the Study Area}

The study was conducted in Gamo Gofa Zone, specifically in Daramalo district which is one of the fifteen districts of Gamo Gofa zone, SNNPR. It is located in North West of Arba Minch, which is side away 12.5 kilometres west from Wolayta Soddo - Sawula main road at Morka /Kucha district Kebele/ and is bordered on the North by Kucha district, on the East by Dita district, on the South by Bonke district, on the South West by Kamba district and on the West by Zala district. Daramalo was part of former Dita Daramalo district. It found at 223 kilometres far apart from Arbaminch (through Arba Minch - Wolayta Soddo - Sawula main road), 210 kilometers from Hawassa and 486 kilometers from Addis Ababa. According to CSA total population of the district is 81,025; males account 51.4 percent $(41,618)$ while females covered the rest 48.6 percent (in absolute term 39,407 ). Daramalo district has 23 rural and one urban kebele. There are three agro-ecological zones; temperate, semi - tropical and tropical. Like 
other parts of the region, agriculture is the main means of livelihood for the population both in terms of crop production and livestock.

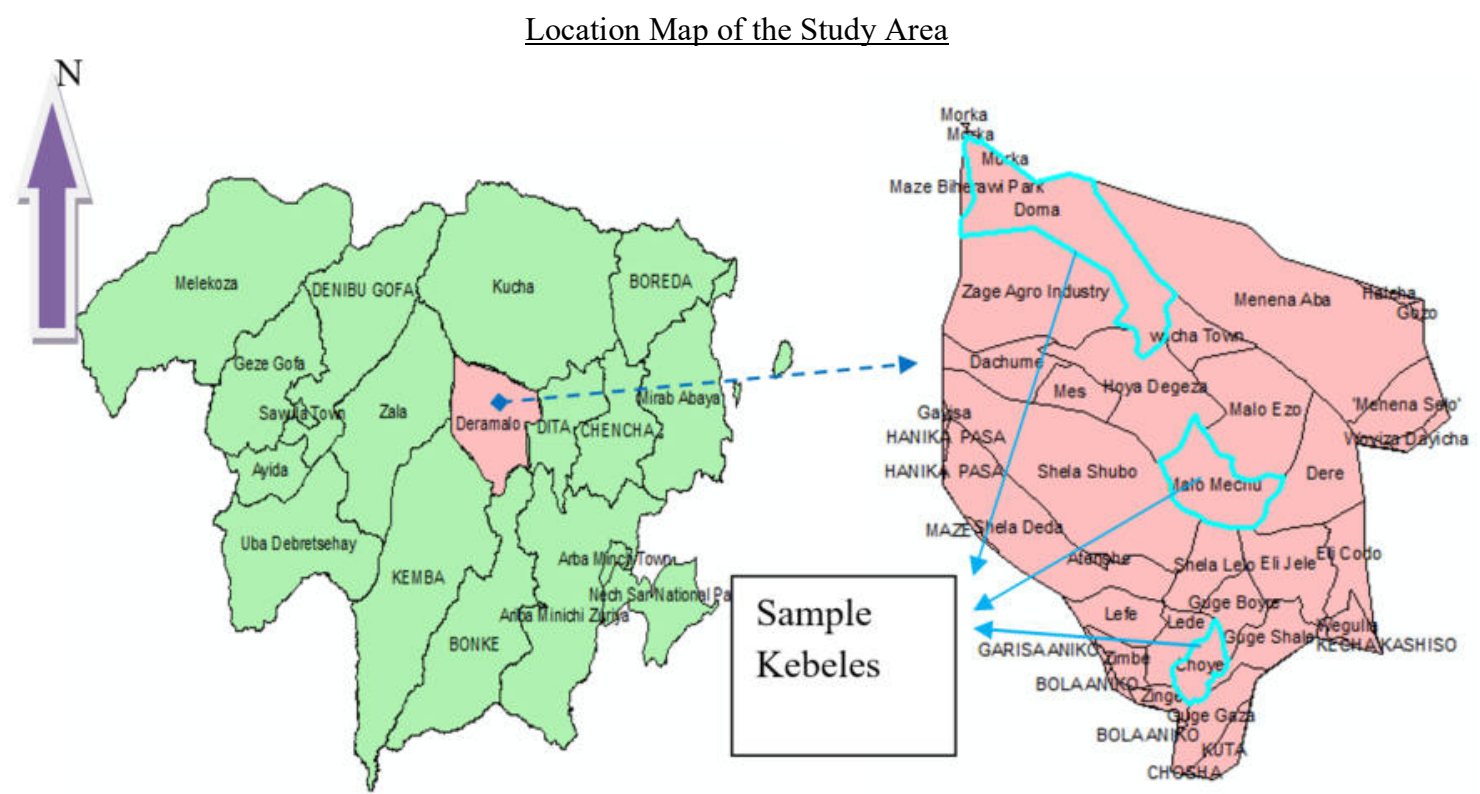

Figure 1. Gamo Gofa Zone Administration Map

Figure 2. Administration Map of Daramalo Distrct

\subsection{Research Method (Design)}

Mixed method was used in this research about child labor as these two types of data complement each other. The quest for factors that contribute to child labor demands qualitative methods. The numbers and the broader information available from the quantitative research methods are quite important for policy makers. In addition to statistical investigation conducting discussion with key - informant and focus group and carrying out observations are crucial to understand the problem in depth. Therefore both quantitative research method and qualitative research method are jointly used for this research.

\subsection{Population of the Study}

The baseline survey conducted by Mission for Community Development Program (MCDP) in 2004 in the SNNPR indicates that children usually inter the labor market starting from the age of five years (PIN, 2009). This age can be used as a benchmark for the rural context in the country when most children start to work under the guidance of adults in the subsistence agriculture. According to the ILO Convention No. 138, in normal circumstances, a person with age of 15 and above may participate in economic activity. Also the Ethiopian Labor Law 377/2003 limits the minimum age to start work at 14 years old. Based on these laws or conventions and experiences, it would be reasonable to consider all children aged 5-14 as population of the study. According to CSA (2007), total populations of children aged from five to fourteen are 25,418 in Daramalo district where 12,223 (48 percent) are females.

\subsection{Sampling Techniques}

Because of time and financial constraints reaching all kebeles of Daramalo is practically impossible. Thus, it is must to take data from part of the population in a way that does not jeopardize the generalization of the result to the district. The study area (24 kebeles) was stratified by three agro- ecological zone, because, child labor considered as different across different agro-ecological zones but similar within the same zone. Since all three stratums have almost equal number of kebeles, it is fair to take equal sample kebeles from each. As a result, after stratification three kebeles were selected by simple random sampling method, one from each stratum. Sampling points also selected by systematic simple random method.

\subsection{Sample Size}

To determine sample size many researchers use different sample size formula.

i. Arbitrary "percentage of thumb" sample size: Arbitrary sample size approaches rely on erroneous rules 
of thumb. Arbitrary sample sizes are simple and easy to apply, but they are neither efficient nor economical.

ii. Conventional sample size specification: Conventional approach follows some convention: or number believed somehow to be the right sample size. Using conventional sample size can result in a sample that may be too large or too small. Conventional sample sizes ignore the special circumstances of the survey at hand.

iii. Proportional sample size method: This overcomes the above listed problems by taking confidence interval, error level, existed prevalence value and adjusted to population. Based on the proportional sample size method, the sample size needed for this study is 353 . This result is arrived based on the following formula.

\section{For infinite population}

$$
\mathrm{n}=\mathrm{z}^{2}(\mathrm{p} \mathrm{q}) / \mathrm{e}^{2}
$$

Where:

$\mathrm{n}=$ the sample size, $\mathrm{z}=$ standard error associated with the chosen level of confidence 95 percent $(1.96), \mathrm{p}=$ estimated percent in the population $(0.52), \mathrm{q}=1-\mathrm{p}, \mathrm{e}=$ acceptable sample error.

Given 30 percent is estimated percent in the population. Therefore;

$$
\begin{aligned}
\mathrm{n} & =\frac{1.96^{2} * 52 * 48}{5^{2}}=\frac{3.84 * 2496}{25}=9584.64 / 25 \\
& =\underline{\underline{383}}
\end{aligned}
$$

$$
\begin{aligned}
& \text { Correction for Population } \\
& \mathrm{n}_{\mathrm{o}}=\frac{\mathrm{n}}{1+(\mathrm{n}-1) / \mathrm{N}} \\
& =\frac{383}{1+382 / 4485}=\underline{\underline{353}}
\end{aligned}
$$

\subsection{Data Collection Techniques and Instruments}

The researcher used agriculture extension workers to collect primary source data, while observation and discussion with district as well as kebele governmental officials and expertise will be held by the researcher. The key points were prepared for discussion with key informant, employers and governmental officials.

Structured and semi - structured interview questionnaires were designed to collect quantitative data.

\subsection{Data Analyzing}

The collected Data was organized systematically in a way suitable for both quantitative and qualitative data analysis. Two level of analysis were used. In the first level simple descriptive statistics like ratios, percentages and means were applied. In the second level of analysis, set the relationship between important variables. The research attempted to pursue new lines of investigation by analyzing and organizing the collected data to investigate the relationship that exists between the variables, that meaning full interpretation, which leads to sound and reliable conclusions, would be made from the results.

\subsection{Model Specification}

There are many options of econometrics model to analyze statistical relation of economic variables. But most widely used econometric models are Linear Probability model, Logit model, Probit model and Duration model.

The linear-regression model applied to a dummy response variable is called the linear probability model. This model is untenable, because the error term is not normally distributed; the variance of the error term is heteroskedastistic, the value of the $\mathrm{R}$ - squared statistic is limited, it does not fulfill the requirement that the estimated value of the dependent variable y lies between zero and one (the predicted probabilities can be greater than one or less than zero).

Probit and logit models are used as remedial to linear probability model. Both models have similar characteristics and very slight differences.

The Probit model: uses the standard normal cumulative density function to explain the behavior of a dichotomous dependent variable. Probability depends upon unobserved utility which depends upon observed variables. When the transformation function $\mathrm{F}$ is cumulative density function (cdf) of the standard normal distribution, the response probabilities are given by

$$
\mathrm{P}(\mathrm{Y}=1 / \mathrm{X})=\Phi\left(\mathrm{X}^{\prime} \beta\right)=\int_{-\infty}^{\mathrm{X}^{\prime} \beta} \Phi(\mathrm{s}) \mathrm{ds}=\int_{-\infty}^{\mathrm{X}^{\prime} \beta} \frac{1}{\sqrt{2 \pi}} \mathrm{e}^{-\frac{1}{2} \mathrm{~s}^{2}} \mathrm{ds}
$$

Logit regression (logit) analysis: uses the logistic cumulative density function. When the transformation function $\mathrm{F}$ is the logistic function, the probabilities are given by 


$$
\mathrm{P}(\mathrm{Y}=1 / \mathrm{X})=\frac{\mathrm{e}^{\mathrm{X}^{\prime} \beta}}{1+\mathrm{e}^{\mathrm{X}^{\prime} \beta}}
$$

Probit and logit models results tend to be very similar. The choice of the model is arbitrary, depends largely on individual preferences. But logit model is simple and easy for interpretation (Fox, 2010). Both probit and logit analyze dichotomous dependent variable rather than survival analysis.

Cox Proportional hazard model: The Cox model is a well-recognized statistical technique for analyzing survival data. Survival analysis deals with making inference about event rates. In survival analysis the Cox model is preferred to a logistic model, since the latter one ignores survival times and censoring information (Söderbom, 2006).

Survival time is the time it takes for a certain event to take place in a given individual. $\mathrm{T}$ is time to event (duration of child work), considered as dependent variable. If the event is observed, it said observed (1); but not, it was censored $(0)$. Time $t$ is some time available to work.

$$
F(t)=P(T \leq t)
$$

Where

$\checkmark \quad \mathrm{F}(\mathrm{t})$ refers to commutative distribution function (cdf) of $\mathrm{T}$ and ranges from 0 to 1 , is non - decreasing function of $\mathrm{t}$, and as $\mathrm{t} \rightarrow \infty, \mathrm{F}(\mathrm{t}) \rightarrow 1$.

$\checkmark \quad$ P stands for probability.

$$
\mathrm{S}(\mathrm{t})=1-\mathrm{P}(\mathrm{T} \leq \mathrm{t}) \text { or } \mathrm{S}(\mathrm{t})=1-\mathrm{F}(\mathrm{t})
$$

$S(t)$ defines the probability of surviving child work longer than time $t$. We can thus interpret the survivor function as the probability of surviving (in the state) past time t. It is positive and ranges from 0 to 1 . It is define as $\mathrm{S}(0)=1$ and $\mathrm{t} \rightarrow \infty, \mathrm{S}(\mathrm{t}) \rightarrow 0$.

Another important function in duration data analysis, which is related to both $F(t)$ and $S(t)$; is the hazard function, which measures the instantaneous rate at which children child labor exist (i.e. no longer survive, ) from the state at time $t$, given that they have not exited before time $t$.

The formal definition of the hazard function is

$$
\begin{aligned}
& \mathrm{h}(\mathrm{t})=\lim _{\Delta \mathrm{t} \rightarrow 0} \frac{\mathrm{P}(\mathrm{t} \leq \mathrm{T}<t+\Delta t / T \geq t)}{\Delta \mathrm{t}} \\
& \frac{\mathrm{P}(\mathrm{t} \leq \mathrm{T}<t+\Delta t / T \geq t)}{\Delta \mathrm{t}}=\frac{\mathrm{P}(\mathrm{t} \leq \mathrm{T}<t+\Delta t)}{\mathrm{P}(\mathrm{T} \geq \mathrm{t})} ; \quad \text { so, for a small } \mathrm{h} \text {, we get the instantaneous rate of exiting per unit }
\end{aligned}
$$

of time:

$$
\begin{aligned}
& \mathrm{h}(\mathrm{t})=\lim _{\Delta \mathrm{t} \rightarrow 0} \frac{\mathrm{F}(\mathrm{t}+\Delta \mathrm{t})-\mathrm{F}(\mathrm{t})}{\Delta \mathrm{t}} * \frac{1}{1-\mathrm{F}(\mathrm{t})} \\
& \mathrm{h}(\mathrm{t})=\mathrm{f}(\mathrm{t}) * \frac{1}{1-\mathrm{F}(\mathrm{t})}
\end{aligned}
$$

Where $\left.f(t)=\lim _{\Delta t \rightarrow 0} \frac{F(t+\Delta t)-F(t)}{\Delta t}\right)$, which is a derivative of $F(t)$.

$$
h(t)=f(t) / S(t)
$$

i.e. the hazard function is the density of exits at time $t$ divided by the survivor function at time t. Hazard the event of interest occurring, it is exit from work. Hazard rate is the instantaneous probability of the given event occurring at any point in time. Hazard ratio also called relative risk. Duration is the number of time units an individual (child) spends in a given state (work).

In many economic applications it seems quite likely that the duration variable $\mathrm{T}$ depends on a set of explanatory variables. Clearly, if there exists a vector of explanatory variables $X$ that impact on $T$, then these variables $\mathrm{X}$ also impact on the hazard rate. Suppose that the variables in the $\mathrm{X}$ vector are all time invariant - i.e. they do not change. To take into account the possibility that time invariant explanatory variables affect the hazard rate, we can write down a proportional hazard model as follows:

$$
\mathrm{h}(\mathrm{t} ; \mathrm{x} \beta)=\mathrm{h}_{0}(\mathrm{t}) * \mathrm{~h}(\mathrm{x} \beta)
$$

Where $\mathrm{X}$ represents child labor specific variables that are assumed to affect the probability of to be child labor and $\beta$ are the model coefficients to be estimated that can describe how each variable affects the likelihood of child participation. The function $h_{o}(t)$ is a baseline hazard function, which is the hazard function of a child labor with all $\mathrm{X}=0$.

By writing it like this, we are assuming that the baseline hazard is common to all individuals while the hazard rate at a given point in time $\mathrm{t}$ differs proportionally across individuals depending on the $\mathrm{X}$ variables. We typically assume that:

$$
h(x, \beta)=\exp \left(\beta_{0} X_{0}+\beta_{1} X_{1}+\beta_{2} X_{2}+\beta_{3} X_{3}+\ldots \beta_{k} X_{k}\right)=\exp \left(X \beta^{\prime}\right)
$$

Therefore the general model of Cox Proportional Hazard model looks like the following.

$$
\mathrm{h}_{\mathrm{i}}(\mathrm{t} / \mathrm{x})=\mathrm{h}_{0}(\mathrm{t}) \exp \left(\mathrm{x}_{\mathrm{i}} \beta_{\mathrm{i}}{ }^{\prime}\right)
$$

Where

$\mathrm{T}$ is time to event (participation of child on work) per day, considered as dependent variable, and $\mathrm{X}$ is a vector of 
explanatory variables that includes the following

1. Poverty: This refers to the well-being of the household. In 2008, the World Bank came out with a revised figure of $\$ 1.25$ a day, is the minimum level of income deemed adequate in a particular country. In study area it may not applicable, because by simple observation, almost all number of people lies under it. So it is better to use more localized criteria. Government of the SNNPR used bench mark to graduate food secure households from the Productive Safety Net Program, which is 3,000.00 birr/household/annual (Agricultural Buruea of SNNPR, 2008). Household considered as poor if its annual income falls below 3,000.00 birr. A poor household may has no choice other than sending children to work. So the expected sign of poverty is positive.

2. Dependency Ratio: The dependant part usually includes those under the age of 15 and over the age of 64 . The productive part makes up the population in between, ages $15-64$. It is normally expressed as a percentage:

$$
\text { Dependency Ratio }=\frac{\text { number of people aged } 0-14+\text { those aged } 65 \text { and over }}{\text { number of people aged } 15-64} * 100-----
$$

As the ratio increases there may be an increased burden on the productive part of the population to maintain the upbringing and pensions of the economically dependent. It leads children to work some productive activities. Therefore, the sign of the dependency ratio is to be positive.

3. Distance of School: It is the distance between residences (home) to school. It is continues variable and measured by kilometer or hours (the time taken to reach from home to school). If the school found at too far from home, it would be difficult and challengeable for young children to attend school. It results schooling not affordable and enable the children to join economic activity works, late entry of school and increase school drop. So it affect children labor positively and child schooling negatively.

4. Credit access: Define as the ability of households to get the demanded amount of money (credit) at any time and place when household needs credit from social funds, Omo Microfinance, RUSACCO, Rural Banks. It is a dummy variable, which is $\mathrm{Cr}=1$, if household access to credit otherwise it is zero. In absences of credit access circumstances, during economic/income shocking seasons or very poor households use child labor as a coping strategy. That means the incidence of child labor increases in the absence of credit access.

5. Sex: Both girls and boys are involved in child labour with the majority being girls. It is dummy variable. Boys labeled by 1 and female by zero.

6. Age: Children age extends from five to fourteen. It will be measured by years. The younger children do vending and domestic work while the ones who would be involved in agriculture were children age become high and high. The expected sign is positive.

7. Broken Marriages and early loss of Parents: A family with complain (mother and father), divorce, inability of mother or father or both by natural and artificial cases, and death of either father or mother or both by any cases while children young. It is a dummy variable, which is one if child has broken $\mathrm{HH}$ or loss of parents. Children those have broken HH or early lost parents forced to work for survival.

8. Mother Education level: The highest education level which achieved by mother. It is continues variable and will be measured by the formal class (grade) level. Mother education has negative effect on child labor through optimal fertility rate. Therefore, the expected sign of it is negative.

9. Father Education level - The highest education level which achieved by father. It is continues variable and will be measured by the formal class (grade) level. Father education has negative effect on child labor due to the fact that higher father education means higher return on adult labor and reduces the probability of children to work. Therefore, the expected sign of it is negative.

Table 2. Expected signs of Explanatory variables

\begin{tabular}{|l|l|l|l|}
\hline No & \multicolumn{1}{|c|}{ Variables } & \multicolumn{1}{|c|}{ Measurement } & \multicolumn{1}{|c|}{$\begin{array}{c}\text { Expected } \\
\text { signs }\end{array}$} \\
\hline 1 & Poverty (P) & Categorical $(\mathrm{P}=1$ if poor; otherwise 0) & + \\
\hline 2 & Dependency Ratio (DR) & Continues & + \\
\hline 3 & Credit Access (CA) & Categorical $(\mathrm{Ca}=1$ if access to credit; otherwise 0$)$ & - \\
\hline 6 & Distance of School & continues & + \\
\hline 7 & $\begin{array}{l}\text { Broken Marriages/Early loss of } \\
\text { Parents }\end{array}$ & $\begin{array}{l}\text { Categorical }(\mathrm{Bm}=1 \text { if broken/lost parent; otherwise } \\
0)\end{array}$ & + \\
\hline 8 & Sex & Categorical (1 stands for Male; 0 for female) & \\
\hline 9 & Age & Continues & + \\
\hline 11 & Mother Education & Continues & - \\
\hline 12 & Father Education & Continues & - \\
\hline
\end{tabular}

There are two coefficients, namely normal coefficient and hazard ratio. The coefficient B result explains nothing but only indicates sign or direction of relation of explanatory variables with dependent variable (T). Exp 
(B) is a hazard ratio (relative risk), which can be interpreted as the predicted change in the hazard for a unit increase in the predictor. For binary covariates, hazard ratio is the estimate of the ratio of the hazard rate in one group to the hazard rate in another group. A positive (negative) coefficient in the model indicates an increase (decrease) in the hazard rate of child labour as well as a decrease (increase) in the probability of survival. If the value of exp (B) is equal to 1 , then there is no difference between the two categories or across the value of variable. If it is more than 1 , it indicates the risk is higher for a categorical variable that coded with one. If the value of exp (B) is less than 1 , then the relative risk of categorical variable with code 1 is than the categorical variable with code 0 by a proportion of $(100 \%-(100 \% * \exp (\mathrm{B})))$.

\section{Results and Discussion}

The purpose of this chapter is to summarize the collected data and the statistical treatment, and/or mechanics, of analysis. It is main part of the thesis and it presents the actual statement of observations including statistics, tables and graphs. It presents the discussion how the hypothesis has been demonstrated by the new research then show how knowledge has been changed by the addition of this new data. It states the researchers' interpretations and opinions, explain the implications of your findings, and make suggestions for future research. Therefore, the result and discussion presented by three sections namely descriptive analysis, diagnostics testes and econometric analysis.

\subsection{Descriptive analysis}

4.1.1. Non - Response analysis

A total of 359 (99.2 percent) of those in the sample of 359 were contacted and agreed to participate and already gave information. The non - response rates defined as the proportion of entities in the sample were non-eligible for data collection to the survey. For $3(0.8 \%)$ unable to contacted, called a unit non - response (non - contact). Proportionally it was 0.8 percent. When the non-respondents differ significantly from the survey population, the resulting errors in the survey data are said to be the result of non-response bias. It make no non - response bias.

\subsubsection{Description of the Sample Respondents}

The household attributes such as economic status, dependency ratio, education level and the presence of credit access would have important implication of child labor in household. Crop production and husbandry are main part of likelihood in the study area and all households participated in this study were farmers. With respect to economic status of households, the study found that more than 85.5 percent of populations in the study area have annual income below 3000 Birr. According to Table 3, in poor household child labor participation is high (97.1\%) with compared to food secured households $(23.1 \%)$. These households may be economically insecure so that children are needed to supplement family income.

Table 3. The Effect of Poverty on Child Labor

\begin{tabular}{lcc}
\hline \multicolumn{1}{c}{ Economic status } & \multicolumn{2}{c}{ Work status } \\
\cline { 2 - 3 } & Not work & Work \\
\hline Food insecure & $9(2.9 \%)$ & $298(97.1 \%)$ \\
Food secured & $40(76.9 \%)$ & $12(23.1 \%)$ \\
Total & $49(13.6 \%)$ & $310(86.4 \%)$ \\
\hline
\end{tabular}

As dependency ratio becomes high the child labor will increase. The average household dependency ratio in the area is as high as ( 80.2 percent) percent with the 59.8 standard deviation. It ranges from minimum 9.09 up to maximum 450 percent.

The credit market in the study area is almost non-existent, the only credit source is Omo-Micro - Finance Institute. It also lends only for critically poor households. However many farmers do not have access to credit. According to this research 228 households (about 63.5\%) need credit to overcome economic problem but fail to borrow money from credit supplying institutions.

Table 4. The Effect of Presence of Credit Access on Child Labor

\begin{tabular}{lcc}
\hline \multirow{2}{*}{ Credit Access Status } & \multicolumn{2}{c}{ Work status } \\
\cline { 2 - 3 } & Not work & Work \\
\hline Access & $22(16.8 \%)$ & $109(83.2 \%)$ \\
No - Access & $27(11.8 \%)$ & $201(88.2 \%)$ \\
Total & $49(13.6 \%)$ & $310(86.4 \%)$ \\
\hline
\end{tabular}

Children in family with complain, divorce or death either father or mother or both work more time for survival or to solve their economic problems. As presented in table 5, about 96.6 percent of children those have lived in broken household were participated in economic activities whereas 86.3 percents children in non-broken household were involved.

Table 5. The Effect of Broken Marriage on Child Labor

\begin{tabular}{ccc}
\hline Household Condition & \multicolumn{2}{c}{ Work status } \\
\cline { 2 - 3 } & Not work & Work \\
\hline
\end{tabular}




\begin{tabular}{lcc}
\hline Broken $\mathrm{HH}$ & $2(3.4 \%)$ & $57(96.6 \%)$ \\
Non - Broken HH & $47(15.7 \%)$ & $253(84.3 \%)$ \\
Total & $49(13.6 \%)$ & $310(86.4 \%)$ \\
\hline
\end{tabular}

Education of household (father and mother education level) is expected to have an important implication for child schooling - child work decision in line with the parental education. Better education background of parents is likely to favor child schooling as the decision maker become more aware of the benefits of investing in human capital.

About 74.4 percent fathers and 76.9 percent mothers were illiterate (never joined formal school) in the study area. However more than 25 parents attended at least grade one in their life. An average education level of fathers and mothers is 1 and 0.64 class respectively. The highest grade completed by fathers is eight and it is grade seven for mothers. This education level is too low to analyze and able to decide overall economic decision as well as child work and schooling.

\subsubsection{Socio - Demographic Characteristics of Child Laborer}

Data were collected from 359 children. There are 158 females (44\%) and 201 males (56\%) in the sample. Forty nine observations are censored (not work) before the earliest event in a stratum and 13 observations are censored (worked less than four hours per day). This study analyzes children remained worked at the end of required time per day (it is four hour).

\section{A. Age of the Respondents}

Children in the age range of 5-14 years were used for the study. More than one -third of the respondents (126 or 35 percent) were in the age group of 8-10 years. About 34.8 percent (125) of them were in the age group $11-14$ and the rest 30.2 percent were in the youngest age group (5-7). Average age of the children interviewed is 9.24 years with a standard deviation of 2.55 . The age distribution of the child respondents were skewed left (skewness $=-0.06)$.

In Figure 3 and 4, X - axis represents years of starting work age. According to Figure 3 and 4 the children start working as early as four years of age. Majority of the children (66.6\%) started working at the age of 5 to support their parents who usually are preoccupied with the subsistence farming in the extremely fragmented plots of land to sustain the family. The average work starting age is about 4.21 years (SD 1.745), which means, they participate in work activities before they celebrate their fifth birth day.

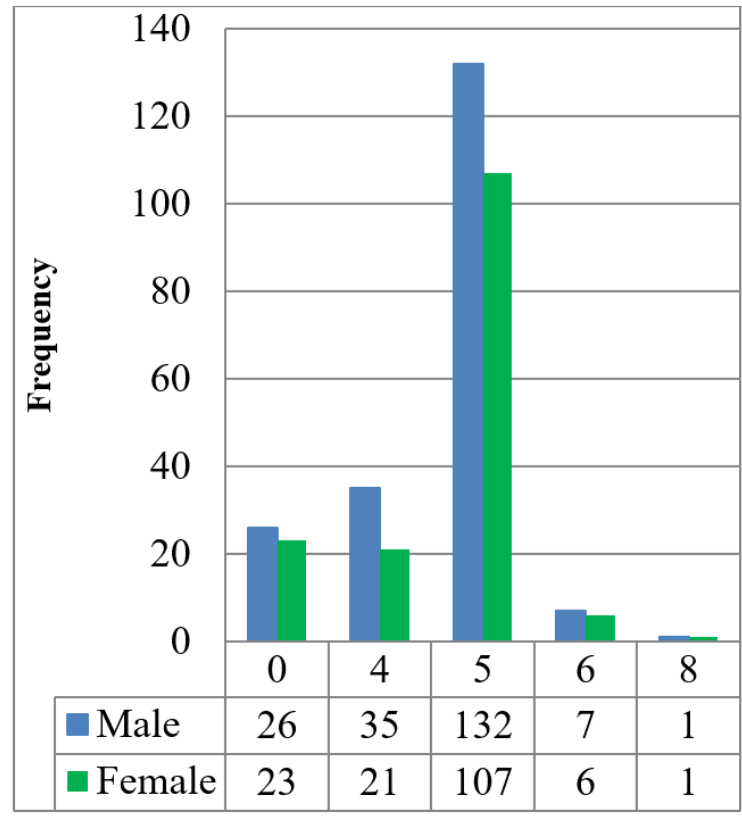

Figure 3. Starting Work Age Frequency

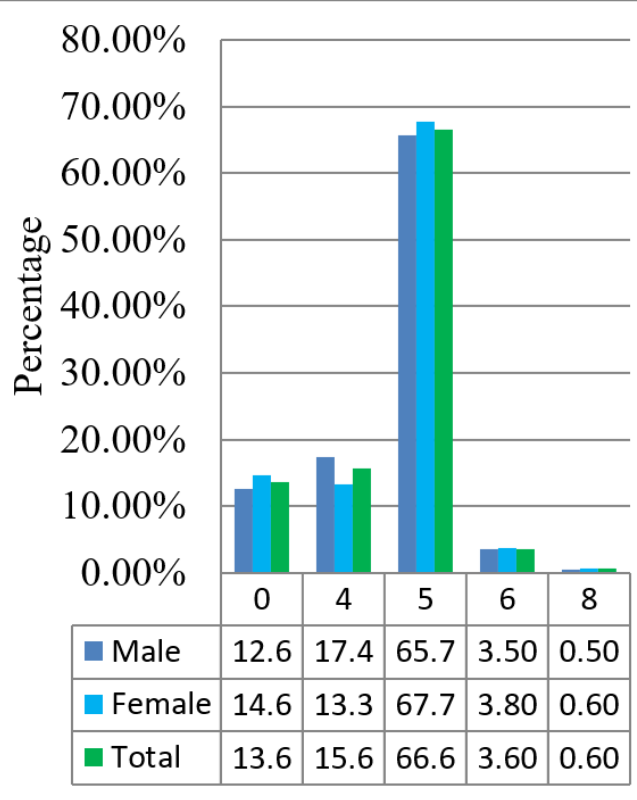

Figure 4. Starting Work Age Proportion

Figure 5. Indicates that at early years of starting work age, the number of children who not work were slightly greater than those who started work. According to the survey result almost all children at age of eight years old engaged in either farm or domestic chores. 


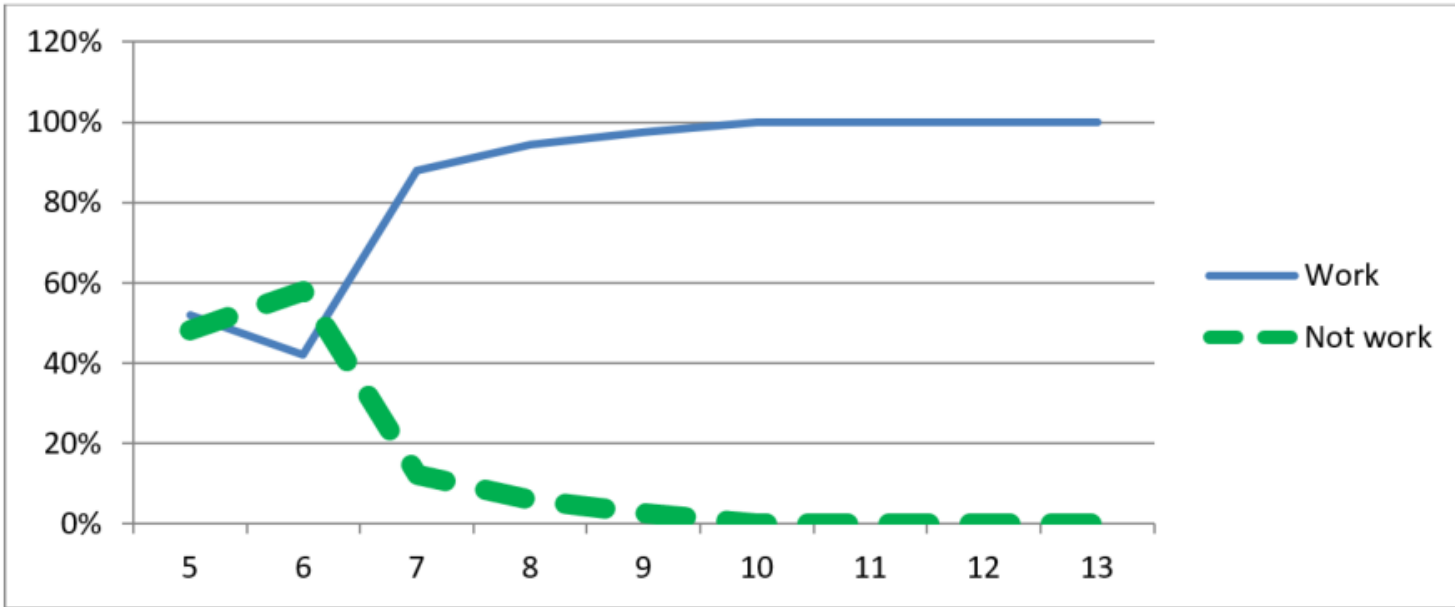

Figure 5. Children Work Participation Rate by Age

\section{B. Sex of the Respondents}

From the perspective of sex, there is no large difference of child labor and its duration between boys and girls. However, the data revealed that work participation of boys is higher (87.1 percent) than that of girls (86.1 percent). The type of work girls and boys carry out in the study area differ only, in that girls add household chores like cooking, cleaning and feeding the families. This however does not mean that boys do not perform these activities at all. Boys also are sometimes responsible to till the land with oxen to assist adults with the guidance of from adults. This is fairly often considered as an increasing where and when the boys should acquire the necessary life skill for the life that comes ahead of them. Collecting fire wood is shared by girls and boys. Both also fetch water from very far away pond, springs or other type of water source although girls are more responsible for this activity.

\subsubsection{Prevalence of Child Labor and Work Condition}

In the study area out of 359 children, 310 (86.4 percent) children were engaged in production activities as well as home chores. The children involved in work in study area are work starting before 6 am in the morning until 1 $\mathrm{pm}$ in the night. According to Understanding Children's Work Project (2008) working 3-4 hours per day considered as normal and have positive sides.

Among 310 working children only 13 children worked at normal circumstances (works below 4 hours per day). i.e., 297 children were worked above 4 hours up to 16 hours per day. Thus, the prevalence of child labour was 82.7 percent. It is slightingly less than the finding of Getnet M. (2010) that was 88 percent in SNNP. The survey reveals that the child labor rate of boy is slightly higher than that of girls (83.1 percent versus 82.3 percent). The study also revealed that most, 66 percent, of those children, who had been working were started the work at age of five years and all children work for family at family farm.

Although there may be different reasons for working, but the sample respondents reported two main reasons. Majority (90 percent) of them reported that their family income was very low and they are forced to work to support their family. Only one - tenth, (10 percent) respondent's wanted to learn some skills which will help them in their future.

In the interviews of the key informants and in the focus group discussion also confirmed that, the motivation of parents for having a child labor are; to help poor children survive, to train children and to teach the children how to manage a decent home (especially for girls).

\subsubsection{Types of Work Children Engaged in}

According to Figure 6, home chores then agricultural activities are the main source of child labor. Many children $(46.24 \%)$ had been participating in both agricultural activities and home chores, where as 37.4 percent children were participating only in home activities. Only 4.9 percent were participating in agricultural activities. 


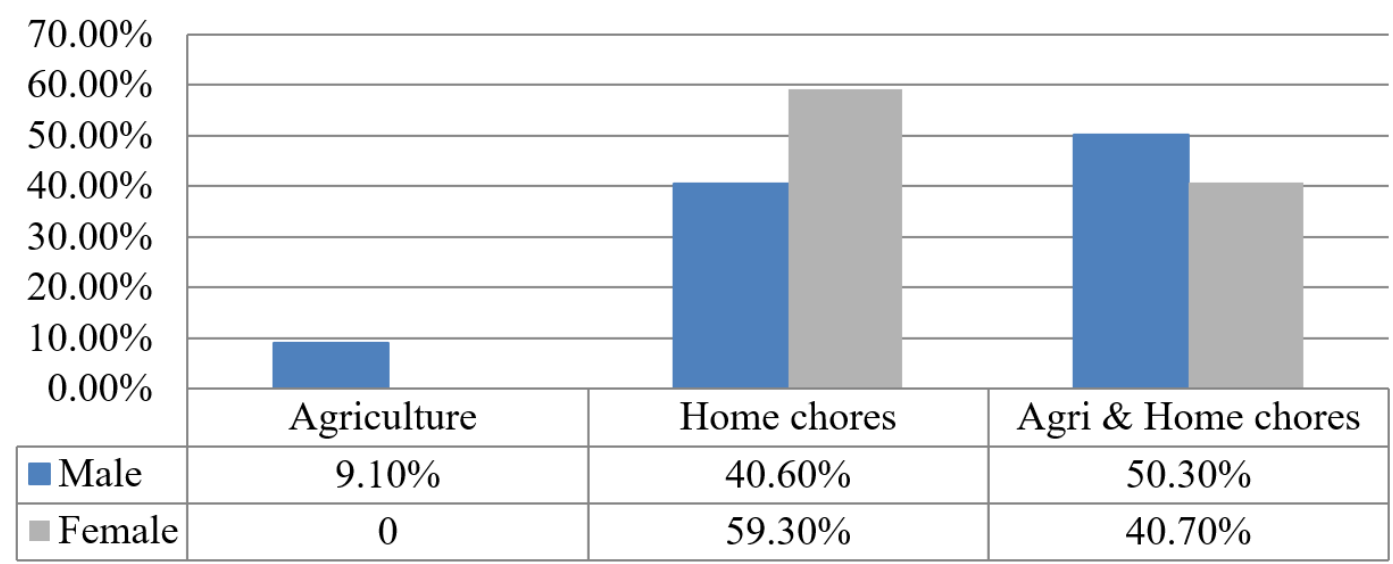

Figure 6. Child Labor Sectorial Distribution

The number of boys dominates girls in combined work of agriculture and home chores, where as the number of girls dominates in home chores but 9.1 percent of boys doing only agricultural activities. Females do not work agricultural activities alone.

Most of boy children are involved in agricultural activities such as tilling the land, sowing, weeding and harvesting crops. Weeding and harvesting of crops are main agricultural sections for child labor. As presented in the Table 6 below, harvesting and weed control accounts 51 percent and 48 percent respectively. Table 6. Types of Work Perform by Children

\begin{tabular}{lccc}
\hline Activities & \multicolumn{3}{c}{ Sex } \\
\cline { 2 - 4 } Tilling & Male & Female & Total \\
Weed control & $75(42.8 \%)$ & $2(1.5 \%)$ & $77(24.8 \%)$ \\
Harvesting & $96(54.8 \%)$ & $53(30.3 \%)$ & $149(48.1 \%)$ \\
Collecting fire wood & $103(58.85 \%)$ & $55(40.7 \%)$ & $158(51 \%)$ \\
Fetching water & $72(41.1 \%)$ & $79(25.5 \%)$ & $151(48.7 \%)$ \\
\end{tabular}

Regarding to home chores, fetching potable water and collecting fire woods are the dominant section; they accounts 47.1 percent and 48 percent respectively.

\subsubsection{Children Working Hours}

Concerning average daily working hours, the majority $(50.4 \%)$ and $66.9 \%$ of the respondents worked for more than 10 hours and eight hours per day respectively, while $14.2 \%$ worked less than 5 hours and $29.5 \%$ worked more than 12 hours.

The children's work load is fairly heavy. Children's hours of work range from three hours to 16 hours per day, in average daily work load of up 10.97 hours; for males it is 10.72 hours and 11.32 hours for females for six days in a week for whole month. In meanwhile children have found in this difficult nature of situation for 5.86 years.

Table 7. Children Daily Working Hours

\begin{tabular}{lccccc}
\hline & Number & Average working hours/day & Standard deviation & Minimum & Maximum \\
\hline Male & 175 & 10.71 & 2.78 & 4 & 16 \\
Female & 135 & 11.32 & 2.78 & 4 & 16 \\
Total & 310 & 10.97 & 2.81 & 4 & 16 \\
\hline
\end{tabular}

The average number of working hours of children for productive activities was 10.8 hours per day for 6 days per week and four weeks in month. So the average number of working hours per week is 65.8 hours, it was more than the normal circumstances which is " 28 - 30 hours per week" (Understanding Children's Work Project, 2008). This find is less than the result that found by Abiy (2002) in Adiss Ababa, which was 80 hours per day.

Therefore the minimum duration of child labor is five hours per day ( 30 hours per week) and the maximum duration is 16 hours per day ( 66 hours per week).

As graph show that number of children those spent 5 and more hours per day to do work were become increase and increase when children get older up to some specific age, around 9 years old; then it was modestly decline up to a certain age, lastly it was rise. 


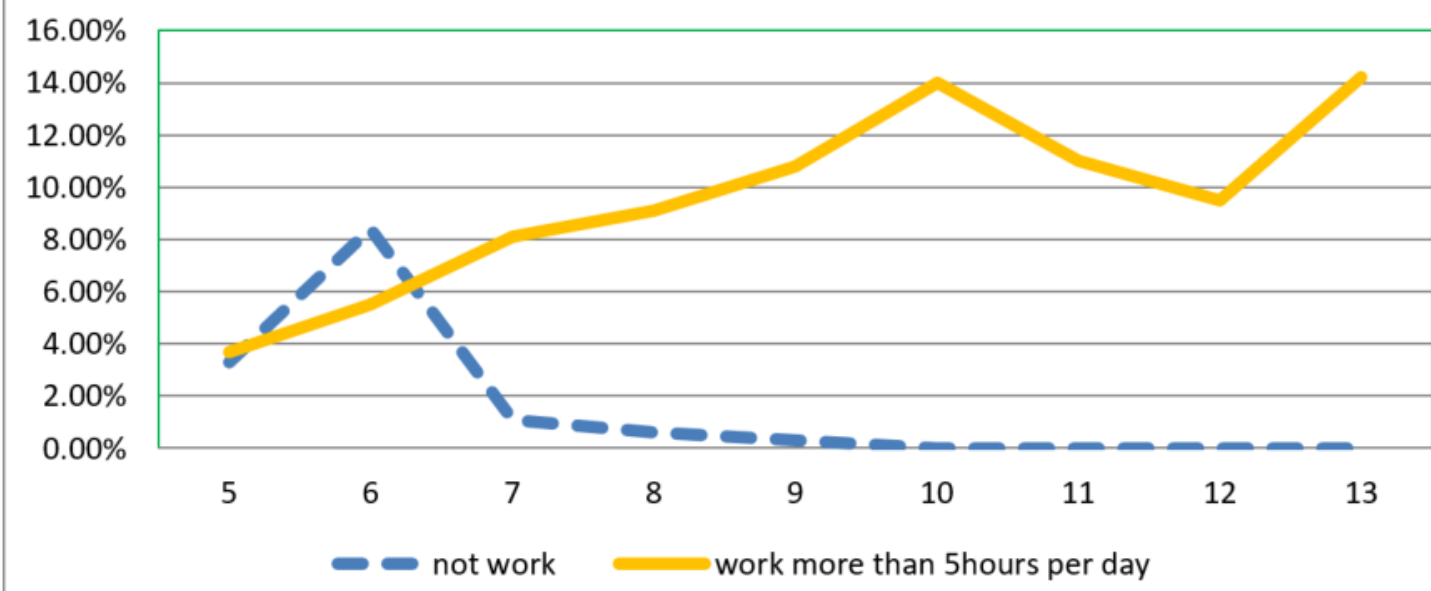

Figure 7. The Age of Children and Time to work per day

This is due to the fact that there was a late entry of school in the study area. Although formal school entry age limited to 7 years, significant number of children start grade one at age of eight to 10 years. When they join school lately, then the time available for work decreases as much as the magnitudes of time spend to school. Even if the decreased time was not equal with the school time, the total time available to work decline by a certain extent of the prior time. After age of 12 the curve shoots up because the children have to do light work as much as possible and they become mature to work. These is the real reason behind the rise and declines of the number of children those who spent more time per day as children become older.

In an effort to be productive, to satisfy their parents, children tend not to eat on time, eat a balanced meal, and have adequate rest for their age and leisure time.

Table 8. Child Labor and Feeding

\begin{tabular}{lccccc}
\hline Sex & Work & \multicolumn{2}{c}{ Eat food } & \multicolumn{2}{c}{ Rest (Break) } \\
\cline { 3 - 6 } & & On time & Not on time & Enough & Not enough \\
Male & 175 & $45(25.7 \%)$ & $130(74.3 \%)$ & $11(6.3 \%)$ & $164(83.7 \%)$ \\
Female & 135 & $28(20.7 \%)$ & $107(79.3 \%)$ & $11(8.15 \%)$ & $124(80.85 \%)$ \\
Total & 310 & $73(23.5 \%)$ & $237(76.5 \%)$ & $22(7.1 \%)$ & $288(92.9 \%)$ \\
\hline
\end{tabular}

As presented in the above table, about 76.5 percent of children those are working were not got food (especially breakfast and lunch) on time. The working children in the study area have very little time to play and socialize the basic needs and rights of children because 92.9 percent of working children have had no enough rest time. These all contribute stunt the physical development of working children. These children also will not develop to be very productive individuals later in their lives like others who were awarded the opportunities to play and socialize during their formative years.

\subsubsection{Child Labor and Education Enrollment}

It is evident from the data that children in the study area have attended grade one up to seven. The average grade completed by children was 2.22 with a standard deviation of 2.25 . Most children in the study population 229 (63.8 percent) were enrolled in primary school. A net enrollment (enrollment at school minimum age, 7 years old) was 131 (57.2 percent) but the rest portion 42.8 percent joined school at late age (age after 7 years old).

According to Table 9, there is still gender gap between boys and girls regarding to gross and net enrollment; boys gross (66.1 percent) as well as net enrollment ( 57.5 percent) more than that of girl's gross rate (60.8 percent) and net enrollment rates (54.5 percent).

Table 9. School Enrollment and Child Labor

\begin{tabular}{|c|c|c|c|c|c|c|}
\hline \multirow[t]{2}{*}{ Sex } & \multicolumn{6}{|c|}{ School Enrollment Status } \\
\hline & Enrollment & $\begin{array}{l}\text { Enrollment } \\
\text { (Net) }\end{array}$ & Not Enrolled & $\begin{array}{l}\text { Currently } \\
\text { school }\end{array}$ & at & Dropout \\
\hline Male & $133(66.1 \%)$ & $77(57.5 \%)$ & $68(33.8 \%)$ & $104(51.7 \%)$ & & $29(14.4 \%)$ \\
\hline Female & $96(60.8 \%)$ & $54(54.5 \%)$ & $62(39.2 \%)$ & $75(47.5 \%)$ & & $21(13.3 \%)$ \\
\hline Total & $229(63.8 \%)$ & $131(57.2 \%)$ & $130(36.2 \%)$ & $179(49.9 \%)$ & & $50(13.9 \%)$ \\
\hline
\end{tabular}

Out all children those covered by the survey 130 children or about 36.2 percent were not currently enrolled at all. Reasons for not enrolling in school are social and economic factors such as age, illness, unwillingness of children and parents inability of family and so on. Among these unwillingness and inability of family to send their children to school took the lion's share which accounts 46 percent out of non - enrolled and 19 percent of total respondents. This means that from school age children population 19 percent children were out of school still now 
due to child labor.

As it is evident from Table 9 above, school dropout rate is about 13.9 percent, which is as much as 14 times more than regional government current year minimum annual school dropout rates goal (1 percent). The survey revealed that high prevalence of school dropout rate mainly is due to the high incidence of child labor. Children often find themselves forced to drop out of school in favor of working in order to help supplement family income or simple to support them. Parents also feel that child should work rather than get education as work bring experience, which in turn provide job security for future.

Many boys and girls combine school attendance and work with increased school enrollment rates. Most children $(61.8 \%)$ were combining education with work to solve the economic problems of their family. It is amazing; only about 1.7 percent children were attending school without done any piece of work.

Table 10. The Trade - Off between Child Work and Education

\begin{tabular}{lllll}
\hline Work status & \multicolumn{3}{c}{ Education } \\
\cline { 2 - 5 } & Not enrolled & Enrolled & Currently at school & Dropout \\
Work & $88(24.5 \%)$ & $222(61.8 \%)$ & $104(51.7 \%)$ & $29(14.4 \%)$ \\
Not work & $42(12 \%)$ & $7(1.7 \%)$ & $75(47.5 \%)$ & $21(13.3 \%)$ \\
Total & $130(36.2 \%)$ & $229(63.8 \%)$ & $179(49.9 \%)$ & $50(13.9 \%)$ \\
\hline
\end{tabular}

By referring Table 10, it is possible to say that the child labor did not highly affect the school enrollment because majority of children's (61.8\%) were working and learning simultaneously. But the effect of child labor on performance of children education was not assessed in this research it needs further investigation. As indicated by Figure 8, at early age the number of children those who did not enter the school was high then approaches to zero while gross enrollment, late entry and dropout rate increase as age's increases.

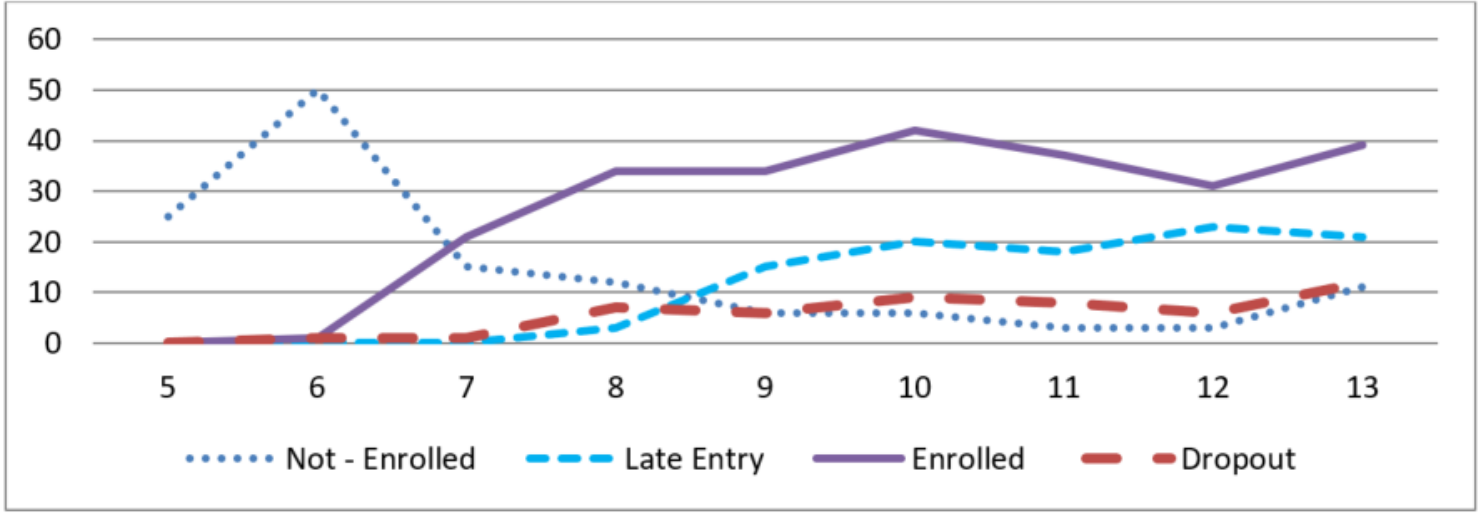

Figure 8. Children Age and School Enrollment

A large number of child laborers are most of the time absent from class. Among school enrolled child laborers about 44 percent are absent at least once a week and four times a month through the year. The discussion with some teachers confirmed that child laborers, when they attend it are difficult to enjoy because they are fighting exhaustion while trying to concentrate in class. Some, in fact, go to sleep in class while teaching is going.

\subsubsection{Hazardous Child Labour}

About 66 percent of children were child labour under hazardous condition. In the study area children have no enough time for rest because they work more than 10 hours per day, averagely six days a week. When they perform work, most of the children use tools that often harm their body. When they use farm equipments or chop different foods with sharp knives cut their hands, legs and other parts of the body. Children walk a long distance, as long as above 10 kilo meter to collect fire wood and collect from unsafe place (exposed for snake and other wild animals, too steep and gallery places). They carry over loaded fire wood, water, harvested crops, market commodities and others along hill road for long distance. Most of the time they also exposed to sun for $6-10$ hours a day (at this interval the intensity of sun is high) and storm. Among interviewed children about 32 percent children do their work at night with no enough light.

Table 11. The Light Condition at Work Place

\begin{tabular}{lcc}
\hline \multicolumn{1}{c}{ Light } & Number of children & Percentage \\
\hline Enough Light & 211 & $68.1 \%$ \\
No Enough light & 99 & $31.9 \%$ \\
\hline
\end{tabular}

Despite such intensive and overloaded works, child laborers were hardly compensated. A large proportion $(99.4 \%)$ of the child workers in study area are unpaid family workers who are mainly engaged in tasks such as the preparation of meals, washing clothes, childcare, cleaning, feeding domestic animals, fetching water and firewood, farm work, family business work as well as the sale of crops in local markets. 


\subsubsection{Child Labor and Interest of Children}

Asked about their motivation and interest to be engaged in child work, most of the child laborer interviewed expressed that they do not have interest in domestic work, but they work merely for survival or were forced by parents. As presented in the table below about 76.5 percent children are not interested in line with their own carrying work.

Table 12. The Interest of Child Laborer

\begin{tabular}{lcc}
\hline Sex & & Interest to continue Work \\
\cline { 2 - 3 } Male & Interested & Not interested \\
Female & $46(26.3 \%)$ & $129(73.7 \%)$ \\
Total & $27(20.0 \%)$ & $108(80 \%)$ \\
\hline
\end{tabular}

Families not buy cloth and provide them with sufficient food when they were denied to work. In addition to this they punished physically by their family and rejected from home.

\subsubsection{The Probability of Child Labor Duration by Hours}

Table 13. Child Labor duration by Hours

\begin{tabular}{ccccc}
\hline Child labor duration by hours & Baseline Cum Hazard & \multicolumn{3}{c}{ At mean of covariates } \\
\cline { 3 - 5 } & & Survival & SE & Cum Hazard \\
\hline 5.00 & .893 & .993 & .004 & .007 \\
6.00 & 3.115 & .975 & .007 & .025 \\
7.00 & 6.548 & .948 & .010 & .053 \\
8.00 & 19.824 & .851 & .017 & .162 \\
9.00 & 33.073 & .763 & .023 & .270 \\
10.00 & 59.187 & .617 & .027 & .483 \\
11.00 & 100.655 & .440 & .028 & .822 \\
12.00 & 172.730 & .244 & .024 & 1.410 \\
13.00 & 282.350 & .100 & .015 & 2.305 \\
14.00 & 635.494 & .006 & .002 & 5.188 \\
\hline
\end{tabular}

As presented by table 13 and figure 9, at beginning the probability of staying in work was 1 then became decline and lastly approaches to zero. That means almost all children work at least five hours per day but the number of children become decrease and decrease when the duration of work per day increase.

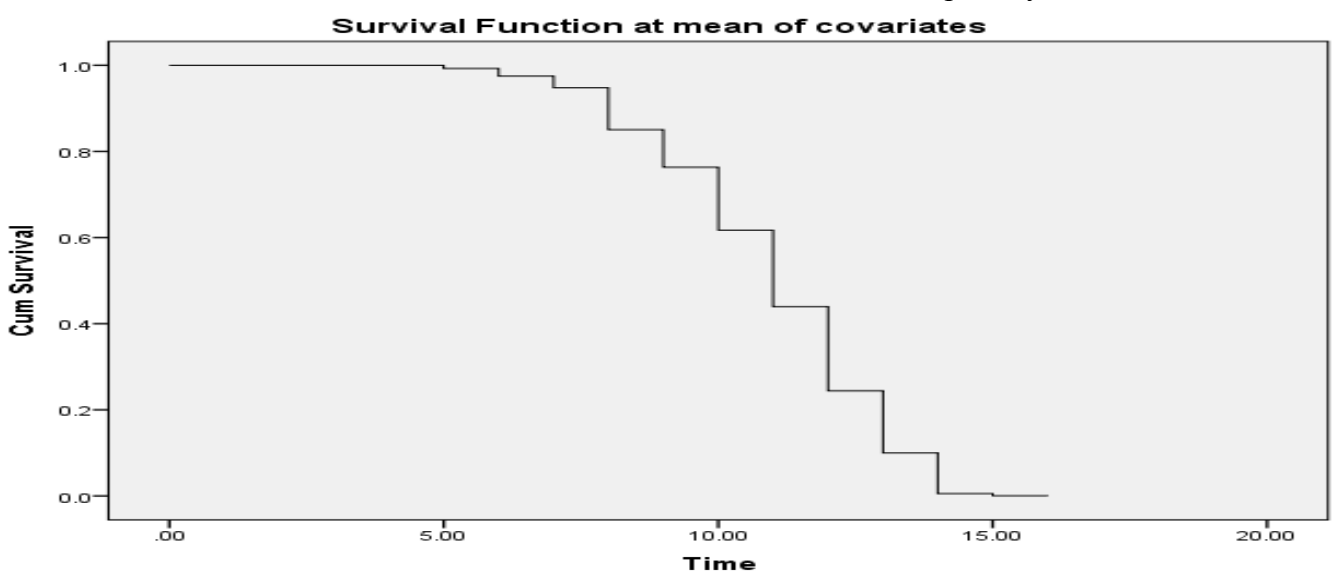

Figure 9. Survival Function of Children

\subsection{Diagnostic Tests}

If two factors are highly correlated, then one of them will be included in the model to reduce the multicollinearity among the factors. Table 15 shows the Preason Correlation Coefficients matrix. So among all variables there is no correlation or strong correlation. 
Table 14. Correlation Coefficients Matrix

\begin{tabular}{lrrrrrrrr}
\hline & \multicolumn{1}{c}{ DR } & \multicolumn{1}{c}{ P } & \multicolumn{1}{c}{ CA } & Sex & Age & BM & DS & Fath \\
\hline P & -0.75 & & & & & & & \\
CA & $0.347^{* *}$ & -0.05 & & & & & \\
Sex & $-0.114^{*}$ & -0.014 & 0.008 & & & & \\
Age & 0.07 & $-0.42^{* *}$ & 0.07 & 0.046 & & & \\
BM & -0.069 & .0 .097 & $-0.13^{*}$ & 0.015 & 0.038 & & & \\
DS & 0.281 & $-157^{* *}$ & $0.23^{*}$ & 0.011 & 0.015 & -0.06 & & \\
FatE & -0.117 & 0.021 & -0.076 & 0.014 & -0.068 & -0.04 & 0.02 & 0.05 \\
MotE & -0.032 & 0.100 & -0.011 & 0.003 & -0.06 & -0.02 & $-0.1 *$ & 0.06 \\
\hline
\end{tabular}

**Correlation is significant at the 0.01 level $(2-$ tailed $)$

*Correlation is significant at the 0.05 level $(2$ - tailed)

Cox Proportional Hazard model has assumptions that need to be verified before its statistical inferences and predictions can be relied upon (Frank E.\& Kerry, 1983). Log - log plots are popular test method (S.Jones, 2005). If the $\mathrm{PH}$ assumption holds, then the covariate effect over different levels of the covariate should be roughly parallel. This means that the effects are not changing over time.

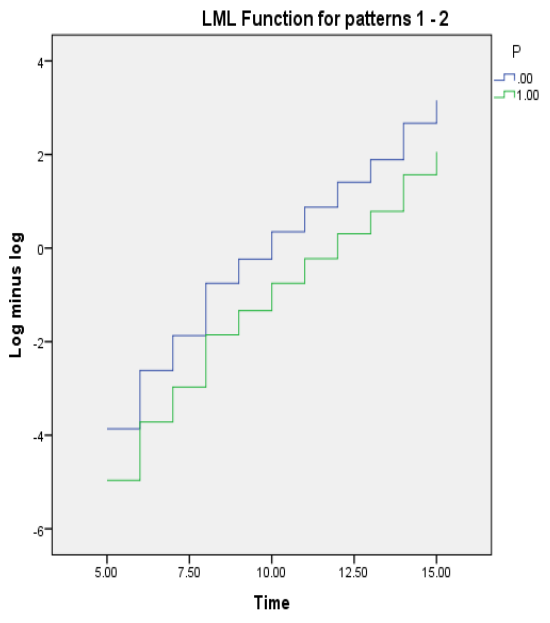

Figure 10. Poverty Log - Log curve

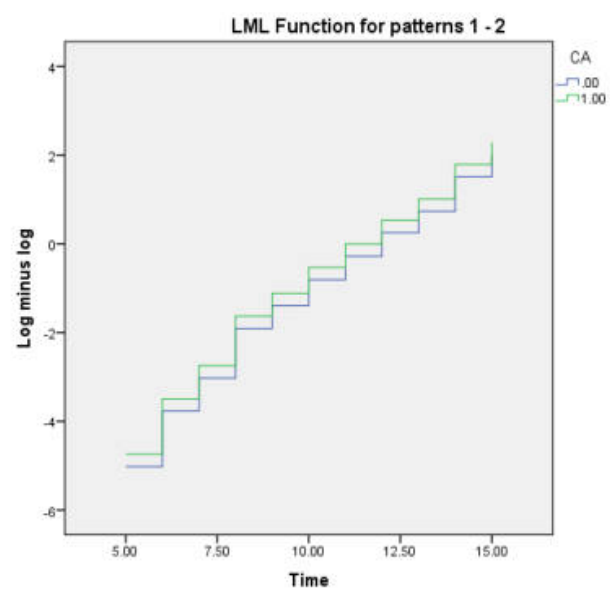

Figure 12. Credit Access Log -Log curve

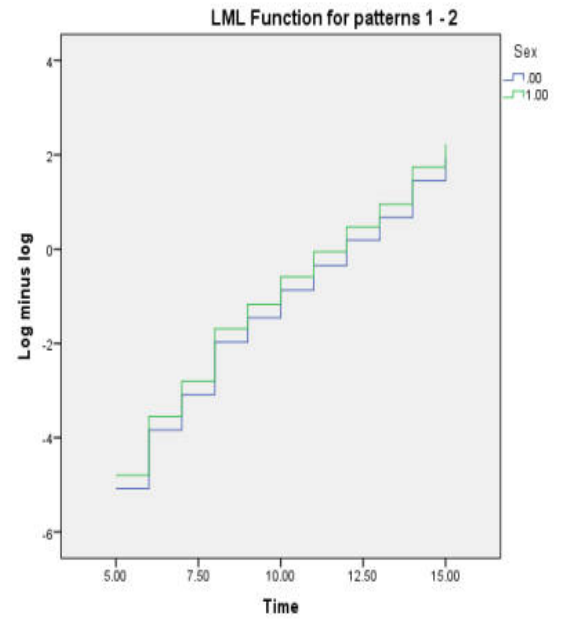

Figure 11. Sex Log-Log curve

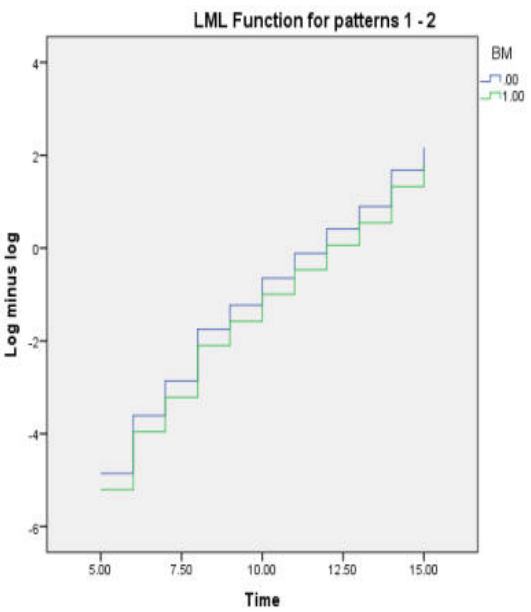

Figure 13. Broken Marriage Log - Log curve

The proportional property holds for sex, poverty, credit access and broken marriage. So, this Cox regression model is good - fitted model for forecasting.

\subsection{Cox Regression Results Analysis}

The estimated results fox Cox Proportional Hazard model are presented in table 16. The regression result indicates that except father education all variables statically significant at 0.05 significance level but all variables including 
father education statistically significant at 0.1 percent significance level.

Poverty is highly significant and results in a higher hazard. The child labor relative risk for a child of poor family is roughly 3.008 times higher than those from non-poor family. The effect of poverty seems to be more significant and is comparable to effects of other covariates.

Table 15 Cox PH Model Regression Result

\begin{tabular}{lrllrrrr}
\hline & B & SE & Wald & Sig. & Exp(B) & \multicolumn{2}{c}{$95.0 \%$ CI for Exp(B) } \\
\cline { 7 - 8 } & & & & & & Lower & Upper \\
\hline DR & -.003 & .001 & 4.490 & $.034^{*}$ & .997 & .995 & 1.000 \\
P & 1.10 & .346 & 10.11 & $.001^{*}$ & 3.008 & 1.526 & 5.928 \\
CA & -.27 & .133 & 4.316 & $.038^{*}$ & .758 & .583 & .984 \\
Sex & -.28 & .123 & 5.316 & $.021^{*}$ & .752 & .591 & .958 \\
Age & -.38 & .032 & 147.1 & $.000^{*}$ & .682 & .641 & .725 \\
BM & .350 & .156 & 5.028 & $.025^{*}$ & 1.420 & 1.045 & .928 \\
DS & -.14 & .034 & 17.50 & $.000^{*}$ & .869 & .813 & .928 \\
FatherE & -.05 & .031 & 3.170 & $.075^{*}$ & .946 & .890 & 1.006 \\
MothE & .103 & .044 & 5.353 & $.021^{*}$ & 1.108 & 1.016 & 1.209 \\
\hline
\end{tabular}

*Significant at the 0.05 level (two - side tail)

** Significant at the 0.1 level (two - side tail)

All group discussion participants agree with the above Cox regression result in that that poverty is the main determinant of child labour supply. Child labour significantly increases the income and the probability of survival of the family. This contribution is most of the time critical since children are sent to work when parents' earnings are insufficient to guarantee the survival of the family, or are insecure so that child labour is used as a mean of minimizing the impact of possible job loss, failed harvest and other shocks on the family's income stream. In other words, child labour is a response by poor households to satisfy basic family requirements.

It become a tradition in the study area that children are often engaged in unpaid family activities in order to free their parents from housework and other agricultural activities so that they undertake paid work. The fact that most of the child laborers are engaged in some work without their freewill, merely for survival and due to family pressure (forced labor) may indicate that poverty is an important factor behind child labor.

The second very influential cause for child labor in the study area is the broken Marriage. Hazard rate of child labor for those who have broken family is as high as 1.42 times the hazard rate of children with unbroken family. The relative risk for broken family child is 42 percent more than that of not.

Children who have broken family and those who lost parents early are forced to work for survival. A family with complain (mother and father), dysfunctional family, unproductive family, divorce, inability of mother or father or both by natural and artificial cases, and death of either father or mother or both by any cases increase the vulnerability of children to work. A dysfunctional family is one plagued by alcohol or drug abuse, violence, or sexual abuse. The remarriage of a parent often gives rise to friction, as the stepparent is sometimes unsympathetic to the children, if not abusive. All these factors can result in unsupportive and unproductive families for children, and can tend to push the children into early (or earlier) work and perhaps abandonment of the household as well.

If one of the parents is absent from the household, children are expected to work more because they have to take over tasks of the missing parent. Therefore we expect that if the father is not present, boys spend more time on family business work and if the mother is not present girls spend more time on housework.

As dependency ratio increase hazard rate of child labor will be decrease by 0.3 percent. Since the dependency ratio is the proportion of under 15 years old children and over 65 years adult to productive family members, the presence of elderly males and females (more than 65 years old) in household is thought to liberate younger children from specializing in work only thereby increasing their potential to attend school. The old peoples (elderly) carry out some works that doing by children such as fetching water, collecting wood, herding, caring child, cooking and even a farm works. In addition to this justification, a family with small number of children usually remains poor as there is less labor force to enhance the productivity of the household to sustain it. It is consistent with the argument that in a larger household with many potential workers, the probability that any single child will be working is somewhat lower.

Household education level has key effect on child labor. As presented in descriptive part an average education level of both father and mother is very low. Mother education has positive and statistically significant effect on child labor. Marginal increases in mother education increase the hazard of child labor by 1.108 times. It seems contrary to ones expectation but in the study area educated mother mostly participated in petty trade whose the return (profit) is not enough to sustain family. When mother participate in petty trade children especially girls will take the responsibility of cooking, caring child, collecting fire wood, fetching water and other duties. Father education, on the other hand, has negative but weakly significant effect on child labor.

Credit access enables households to smooth consumption during economic shocks. This reduces child labor as manifested by their negative. Credit access also affects child labor by reducing household poverty. In the study 
area, the only source of credit is Omo Micro - finance Institution that provides credit selectively for critically poor farmers. Credit is also provided for food insecure farmers by Daramalo district Agriculture office. But such provisions will have only short run effect because the credit was not given to farmers based on effective business plan. After provision (distribution) of the credits there is no follow up and technical support. There is miss usage of browed money. Most of the time they not spent on value added things rather than current consumption, so they remain as poor/food insecure.

Boys and girls are assigned different societal roles and experience different perspectives of life just because of their gender difference. The above regression result indicates that child labor risk rate of boys' was 0.752 times less than that of girls. In other expression, girls those found at risk were 22 percent more than the boys. Due to some cultural biases girls are often kept at home to help their mothers at work whereas boys are sent to school. The societies thought regarding to girls education is that, in the future girls school return is not for family. They say it is for husband. So they prefer to send their girls to work rather than school.

Age is also negatively signed, which suggests that an increase in age will decrease the hazard rate, thus increase the probability of survival. With increased age, the hazard is reduced by 22.8 percent each year. The younger the child starts to work the more vulnerable he/she becomes to workplace hazards, exploitation and ill treatment. The physical and mental development of very young children could be seriously affected through long hours of work, exposure to harsh climatic condition, work that is too heavy for young bodies, and accidents. If the ages of children increase children become mature enough even to resist unsafe works. Otherwise, they are forced to engage on works that are so heavy and difficult to carry out and hurt them physically, psychologically and mentally more than matured children.

Distance to school: the above regression result did not support the hypothesis of the researcher. In the hypothesis the relation of distance of school and child labor were explained as positive but the regression result now is negative and statistically significant. The regression result shows that an increase in distance of school from child's home by 1 kilo meter decreases the hazard rate of child labor 0.869 times. Due to 1 kilometer increase of school distance the child labor will decrease by 13.1 percent. This may be due to the facts that most children undertake work and schooling parallely. In such cases, students who live close to schools are exposed to work more hours before and after school and even at break and lunch time and families also have opportunity to control children at near. However, when school distance is far from home children take many hours to walk before or after school which reduce the work time compared to those who live nearby school. Families have also no chance to control children before and after school at road.

To sum up, the study clearly showed that factors such as dependency ratio, broken family, age and sex of children, credit access and parents' education; and most importantly, poverty, are the major factors that expose children to child labor. Child laborers could not get food on time, work long time and have no time to enjoy rest and work under hazardous condition. Their education, health, growth and development are threatened.

\section{Conclusion and Recommendation}

\subsection{Conclusion}

Children are the blooming flowers of the garden of society and valuable assets of a nation. The welfare of the children is strength the social and economic development of a country. Paradoxically, child labor is sad reality of our country and world as well.

The principal motivation of this study was to answer the prevalence's and main causes of the child labor in the study area. The study confirmed the prevalence of child labor was high, 82.7 percent, which is among highest incidence at country level as well as in world. It has shown quite clearly that almost all child labor is forcefully taking place in the family farm/household chores without any payment. Their work conditions are rather dangerous, often not providing the stimulation needed for proper physical, mental, and emotional development. Most children in the study area (63.7\%) are currently enrolled while 36.3 percent are not currently enrolled at all. Reasons for not enrolling in school include age and non willingness of child and inability of parents. A large number of child domestic who are enrolled in school can work, about 97 percent of enrolled children.

Different factors worked together in pushing and pulling children to be child laborer and attempts are made to identify the major factors that are peculiar to the study area. Poverty has strong and significant effect in exposing children to child labor and abuses upbringing and growth of the child. This is because consumption needs cannot be met from other sources. Most of households (85.5\%) included in this research is poor, illiterate and have no enough credit access. Children from poorer households are more likely to work and less likely to attend school than children from richer households. A broken household also highly causes child labor. Another interesting result is a parent education level, is an important determinant of child labor; mother and father education has strong and weak effect on it respectively. Given that Ethiopia is relatively high fertility society, the average dependency ratio is 80.2 percent which has negative and significant effect on child labor.

Next to household characteristics, children sex and age difference have significant effect on child labor. The central message from this study is that girls are more likely to work and less likely to attend school than the boys. 
The finding regarding the age of children indicate that the average age of the working children is as low as 4.21 years but some begin working as four years old; and average about 11 hours of work per day for 6 days in a week. Long hours of work could leave children too tired to concentrate on their education and hazardous health conditions could permanently reduce their ability to learn. Have no time for recreation and leisure as they work on the average 11 hours per day. If they are exploited at very early age, they would not be able to contribute to the country and would hamper progress.

In summary, child labor is long lasting phenomena of the study area and it will not be eliminated in the near future. Because the principal cause of child labor is poverty we cannot over through it within short period of time rather than reduce significantly, it takes long time to reduce.

\subsection{Recommendation}

As discussed in this paper child labor is serious negative phenomenon of our world that requires joint contributions of all societies and multi - directional approaches. The desired areas of intervention stated by the subjects included family support to alleviate poverty, provision of free education to children, raising community awareness about child labour, family planning, legislation, and law enforcement on child labour.

The most effective and soundful instruments for reducing the incidence of child labor lie in progress made to reduce poverty by putting short run and long run solutions. If the work of children is needed for meeting the essential needs of the family, any effort to reduce child labour (both in formal and informal occupations) may take into account that the income of families involved will be affected negatively, often pushed below the survival level. Hence income transfers and/or subsidies for poor families with children in school or income generation programmes become crucial importance for the effectiveness of child labour reduction programs.

Create job opportunity for parents reduce child labor, large government infra structure construction such as rural roads, water, building constructions and others one way of creating job opportunities.

In the long run, increase in agricultural productivity both crop and animal production recommended by the researcher. Make their farming system modernize, provides agricultural inputs with low price and adequate technical supports. As key informants told most of the time there was no adequate technical support, as a result, a technology adoption was failed. Provide credit access as much as they need with sounded business plan and reasonable regular technical assistance. To do so, organize well structured and functional credit and saving primary cooperatives.

Education also may be the most important tool to reduce child labour. Accessible and qualified primary school of good quality should be the showpiece of any strategy to eliminate child labour. Making education truly free is a first step toward increased enrolment rates. The poor are highly sensitive to school fees because such fees can represent a large share of household income.

Social mobilization plays an important role in engaging a broad range of social actors in efforts against child labor. Creating awareness among all societies, government bodies, NGOs and other responsible bodies make influential power to prevent Child labor. Family should be advised to handle their children in a proper way. Organize discussion session at regular basis at society level to prevent child labor, to enroll all school age children to school and to minimize school dropout rate by society participation. The use of a wide variety of conventional (e.g. radio, television and printing media) as well as non - conventional communication channels (e.g., religious leader and tribal leaders, school teachers, health care workers) is important in order to achieve maximum outreach. Mobilize some resources at community level to address vulnerable children by providing food, by giving school materials such as text book, pen and uniform and other support. Government may create awareness for youths, adults and church leader to build good marriage.

Establishing and strengthen child right clubs and children Parlama at school, at village, kebele and district level is good mechanism to reduce child labor. To solve the problem, the cooperation of many, namely, parents, employees, governments, academicians, voluntary agencies, non-governmental organizations, policy makers, and the official machinery is essential. Therefore, establishment of community child protection net works and monitoring mechanisms also one way to prevent child labor. Strengthening of the legal framework and enforcement of current laws - create a clear system of enforcing the various legislation in working with, schools (compulsory education), community leaders, Churches and NGOs on child labor.

The establishment of a comprehensive and effective birth registration is essential component of any effort to enhance the national response to child labor. This enables children to enter school at minimum school age and may reduce child labor.

Although dependency ratio has negative effect on child labor, it is important to control population growth. The researcher suggests the need for policy makers to initiate meaningful programs such as family planning because most households have high family size with low land holding and assets.

The researcher suggest that local government in order to reduce time spent on collecting fire wood and to save children labor and time, distribution of power save - stove that made from local available materials is remedial measure to reduce child labor. Reducing the distance to water sources by constructing wells and piped water 
sources in all villages by joint force of government, NGOs and community as whole is recommended policy option. Since most child combined work with education, that indicates work slightly affects the gross enrollment, so the researcher suggest further investigation (research) on effect of child labor on performance of children school.

\section{References}

Abiy, K. (2002). Ethiopia Child Domestic Workers in Addis Ababa: A rapid assessment, Working Papaer.

Admassie. (2002). Explaining the High Incidence Sub - Saharan African, Discussion Paper, ADB, Blackwell press.

SNNP Agricultural Brueue (2008). PSNP Graduation manual. Graduation manual .

Alegnta, F. (2007). Child Labor in the Informal Sector: A Study on the Impact of Child Labor in the Case of Children who are Engaged in Blacksmithing Activity in Kolfe- Keranio Sub- City. Social Work Thesis Research.

Altaye, Ababi, Derege, Mesfin, Menelik, Teferea, Debela, Girmay. (2006). Child Labor and Childhood behavioral and mental health problems in Ethiopia (specifically in Addis Ababa, Nazzareth, Hawassa and Bahirdar). Ehiopia.J.Health Deve.

Andvig,Canagarajah,Kielland (2001). Issues in Child Labor in Afirica. Working pepare series 26701.

Andving (2001). Family - Controlled Child Labor in Sub - Saharan Africa; A Survey of Research, Social Protection Unit and Human Development Network of the World Bank.

Brown, Deardorff and Stern (2002). The Determinants of Child Labor: Theory and Evidence, The school of Public policy the University of Michingan Press.

C. Rosati and M. Rossi (2001). Children's Working Hours and Child School Enrolment and Human Capital Accumulation: Evidence from Pakistan and Nicaragua. Understanding Children's Work .

CSA (2001). The Child Labor Survey Report.

CSA (2007): Populationa and House Census Data. retrieved from www.csa.gov.com.et.

Daramalo district Adminstrationn Council (2012 ): Annual Report of Daramalo District Administration Council.

Edmonds, E. (2008). Defining Child Labour: A Review of the definitions of Child Labour in Policy Research. Geneva: ILO.

Eshetu andTeshome (2014): Child labor Exploitation and Children participation in Education: Astudy in selected Shools at Debube Omo Zone, Arbaminch, Arbaminch College of Teachers Education; . Retrieved fromhttp://www.academia.edu/9654718/child_labour_exploitation_.Fox, J. (2010): Logit and Probit Models. York SPIDA

Galli (2001): The Economic Impact of Child Labor, Working Paper, World Bank, 8.

Getinet and Beliyou (2007): Child Labor and Child Schooling in Rural Ethiopia: Nature and Trade - off, Addis Ababa University.

Gurcello, Lyon and Rossati (2006): The twin challenges of child labor and youth employment in ethiopia. working paper.

Guarcello and Rosati. (2007). Child Labor and Youth Employment: Ethiopia Country Study, Working Paper.

Habtamu. (2011). Livelihoods And Survival Strategies Among The Migrant Sho - shinning Children: A case study at Arada Sub - City,Addis Ababa. Ma Thesis .

Heady, C. (2000). What is Effect of Child Labour on Learning Achievemnet? Evindnce from Ghan. Innocenti Working Paper No.79.

IPEC, I. (2013). Making Progress Against Child Labor - Global Estimates and Trends 2000 - 2012, Working Paper. Johansson, J. (2009): Causes of Child Labour: A Case Study in Babati Town. Bachelor's Thesis 15 ECTS .

Lomi. (2002). Child Labor in Northern Addis Ababa: The case of Weavers Around Shiro Meda Area, MA Thesis. MOE. (2011). Educational Statistics Annual Abstract 2003 E.C/2013 - 11 G.C. MOE.

Narag T. (2009): Child Labour And School Attendance: An Empirical Study.

Negarit Gazatta (2004): Labour Proclamation No. 377/2003, Negarit Gazetta, 10th year, No.12. Proclamation .

Negarit Gazetta (2007): Federala Civil Servant Proclamation No. 515/2007, Negarit Gazetta, 13 th year, No. 15. Proclamation .

Ndem, Michael and Awa. (2012). Child Labor in Nigeria and Its Economic Implications: A case study of Calabar Municipality, Research on Humanities and Social Sciences vol.2, Nigeria.

Peoples In Needs (2009): A Study on the Situation of Child Labor in Ethiopia: Review of Existing studies and Brief Assessment, Addis Ababa.

Pranab Bardhan and Christopher Udry. (1999). Development Microeconomics. Oxford University Press Inc, New York.

Primary School Net and Gross Attendance Rates, E. (2005): Retrieved from http://www.epdc.org/sites/default/files/documents/Ethiopia_coreusaid.pdf.

Ray and Lancster (2003). Does Child Labour Affect School Attendance and School Performace? Multi Country Evidnece on SIMPOC Data. School of Economics University of Tasmania Hobar Australia. 
Ray R. (2000): Poverty, Household Size and Child Welfare in India. Economic and Political Weekly Working Paper, 35.

Save the Children (2003): Children's Rights in Ethiopia. A Situation Analysis , 43 -44.

Söderbom, M. (2006). Applied Econometrics. Lecture note 10 , 1 -7.

Solomon and Alemu (2003): A Study on Child Labor in Three Towns of Southern Ethiopia, Hawassa, Wolyta Sodo and Arbaminch, Journal Article.

Tseganesh W. (2011): Determinants of Child Labor and Schooling in Rural Households of Ethiopia, Addis Ababa University, MA Thesis.

UIS and GMR (2014): Progress in Getting All Children to School Stalls but Some Countries Show the Way Forward. Policy Paper 14/Fact Sheet 28.

UNESAD (2013): World Population Prospects: The 2012 Revision: Key Findings and Advanced Tables. Working Paper ESA/WP.227 .

UNESCO (2003): Data Sheet. Retrieved from http://en.unesco.org/.

UNICEF and MoFED (2013). Investing in Ethiopia Boys and Girls Yesterday, today and tomorrow, Book, Amharic ed.

Yacouba D., Alex E. and Farhad M. (2013): Global child labour trends. Retrieved 2012, from http://www.ilo.org/ipecinfo/product/download.do?type=document\&id=23015.

Zegers (2013): Interim Evaluation of the E - FACE project in Ethiopia, Situation Analysis.

Zelalem D. (2010): Child Labor, Agricultural Shocks and Labor Sharing in Rural Ethiopia, Erasmus University, MA Thesis .

Zelalem Y. (2010). Child Labor, Agricultural Shocks and Labor Sharing in Rural Ethiopia, Working Papere, World Bank.

Zewdineh H. B. (2008): Review of the Legal and Policy Freameworks Protecting the Rights of Volunerable Children in the Federal Democratic Republic of Ethiopia. Journal Article . 